Egyptian Journal of Aquatic Biology \& Fisheries Zoology Department, Faculty of Science,

Ain Shams University, Cairo, Egypt.

ISSN $1110-6131$

Vol. 25(5): 1033 - 1061 (2021)

www.ejabf.journals.ekb.eg

\title{
Effect of the biotic and abiotic factors on the abundant species of macrobenthic invertebrates in northern Khors of Lake Nasser
}

\author{
Isaac A. Iskaros ${ }^{*}$; Mohamed R. Fishar ${ }^{1}$; Hoda M.A. Wahab ${ }^{2}$ and Nagla E. Mohamed ${ }^{1}$ \\ 1- National institute of Oceanography and Fisheries, Cairo, Egypt. \\ 2- Zoology Department, Faculty of Science, Aswan University, Egypt. \\ Corresponding Author: isaaciskaros@gmail.com
}

\begin{abstract}
ARTICLE INFO
Article History:

Received: Nov. 7, 2021

Accepted: Nov. 19, 2021

Online: Dec. 9, 2021

\section{Keywords:}

Lake Nasser,

The northern Khors,

Water quality,

Macrobenthic

invertebrates,

Species composition
\end{abstract}

\section{ABSTRACT}

Major macrobenthic invertebrates' groups along with the surrounding environmental conditions of four important khors located in the northern sector of Lake Nasser were seasonally analyzed during 2015. For better understanding the community structure and the diversity of the main functional groups of organisms, the following parameters were considered: temperature, transparency, electrical conductivity, hydrogen ion concentration, dissolved oxygen, nitrite, nitrate, orthophosphate and chlorophyll-a. Besides, type of sediments and their contents (organic matter and calcium carbonate) and heavy metals (iron, manganese, zinc and copper) were also determined. A number of 27 taxa, belonging to 16 families of macrobenthic invertebrates, were encountered in the northern khors of Lake Nasser. Specimens contained 10 chironomid larvae, 3 odonate nymphs, 5 annelids, 5 molluscs, 1 decapod and 1 adult corixid. In addition, 2 unknown species belonging to ephemeropteran nymphs and trichopteran larvae were identified. The combined contribution of aquatic insects, molluscs and oligochaetes constituted the abundant groups of khors' macrobenthic invertebrates throughout the study period. The highest density of macrobenthic invertebrates was recorded at the littoral sites of Khor El-Ramla (ann. aver. 3262 ind. $/ \mathrm{m}^{2}$ with $15.5 \mathrm{GFW} / \mathrm{m}^{2}$ ) and Khor Kalabsha (ann. Aver. 2983 ind. $/ \mathrm{m}^{2}$ with $19.8 \mathrm{GFW} / \mathrm{m}^{2}$ ) accompanied with some patches of submerged macrophytes. The declined density values were observed at Khor Rahma (ann. aver. 825 ind $/ \mathrm{m}^{2}$ with $9.8 \mathrm{GFW} / \mathrm{m}^{2}$ ), where most of the aquatic plants disappeared. Shannon $(\mathrm{H})$ diversities of those communities were measured. The results of the analysis variance on SPSS and Pearson correlation coefficient showed that water temperature, transparency, electrical conductivity, hydrogen ion concentration, dissolved oxygen, Chlorophyll-a, nitrite, nitrates orthophosphate, organic matter and calcium carbonate are the most influential parameters on different groups of macrobenthic invertebrates at varying degrees. The data obtained in this investigation would be crucial to understand macrobenthic invertebrates' regulation and would hence contribute to the knowledge regarding the limnology of Lake Nasser, particularly after the establishment of Renaissance Dam in Ethiopia.

\section{INTRODUCTION}

Lake Nasser is a subtropical monomictic and eutrophic lake (Hussian et al., 2015). The only source of its water is the River Nile. The outflow is the continuation of the Nile towards the North. The Nile flood comes once a year in mid-summer originating from the Ethiopian Plateau and extends to late autumn. 
Macrobenthic invertebrates' populations under investigation are among the most diverse and abundant constituents of the freshwater biota. They include representatives of many organisms, such as Aquatic Insecta (ex.: Larvae of Diptera, nymphs of Odonata and Ephemeroptera, larvae of Trichoptera and larvae and adult stage of Hemiptera), Mollusca (Gastropoda and Bivalvia), Annelida (Oligochaetae and Hirudinea), Crustacea (Decapoda) and Platyhelminthes (Merritt et al., 2008). They provide the base of food web for the freshwater habitats worldwide. These biota integrate the change in physical, chemical and ecological characteristics of their habitat, and they play a key role in the cycling of material and in energy flow. Furthermore, they appear to be critical when considered for ecological and biodiversity assessment (Silva et al., 2014).

The study of macrobenthic invertebrates in Lake Nasser has received a minor interest. The $1^{\text {st }}$ survey on those biota was carried out in the study of Entz (1978) who mentioned a gradual change in the components of benthos with the development of the lake, particularly molluscs and oligochaetes. Latif et al. (1979) studied the distribution of benthic fauna of both Lake Nasser and Lake Nubia (only in the main channel) in March and July 1979, respectively. He found that the major components of benthic fauna in Lake Nasser were oligochaetes, while thoseof Lake Nubia were mainly of molluscs.

Detailed investigations were carried out by in the studies of Iskaros $(1988,1993)$ conducted on the distribution and seasonal variations of macrobenthic invertebrates in Lake Nasser and adjacent waters (Aswan Reservoir and the River Nile) in relation to the prevailing environmental conditions. He identified 40 species for the $1^{\text {st }}$ time, in relation with the aquatic insects, annelids, molluscs and Platyhelminthes. Fishar (1995) recorded 39 species of macrobenthic invertebrates. Although 14 species were previously recorded in the study of Iskaros (1988, 1993), they were not included in the identified list of Fishar (1995) who added 9 species. In the recent years, Iskaros and El-Dardir (2010) identified 10 species (4 chironomid larvae, 3 oligochaetes and 3 molluscs) from the offshore stations of ten sectors with depths exceeding $50 \mathrm{~m}$. Mola and Abdel-Gawad (2014) and Wahab et al. (2018) carried out a review on macrobenthic invertebrates and recorded 24 and 26 species, respectively, and these taxa were previously known by other investigators.

The present investigation had two targets; namely,

1- To evaluate the important physical and chemical parameters to determine the relationship between these parameters and the studied taxa.

2- To study and analyze the biodiversity of macrobenthic invertebrates and use them as bioindicators for the water quality.

\section{STUDY AREA AND METHODS}

\subsection{Study area}

The shoreline of Lake Nasser is very irregular, with numerous side extensions known as khors. There are about 85 long khors, of which 48 are on the eastern side of the lake and 37 on the western side. Their surface area is about $76 \%$ of the total lake surface. Khors El-Ramla, Kalabsha, Rahma and Wadi-Abyad were selected as study areas being shallower than the others and possessing considerable areas (Table $1 \&$ Fig. 1). The climate of this area is defined by aridity and hot summer with maximum temperature that may reach $47^{\circ} \mathrm{C}$. 
Table 1. Dimensions of the four northern khors in Lake Nasser at $180 \mathrm{~m}$ above mean sea level (Latif, 1974).

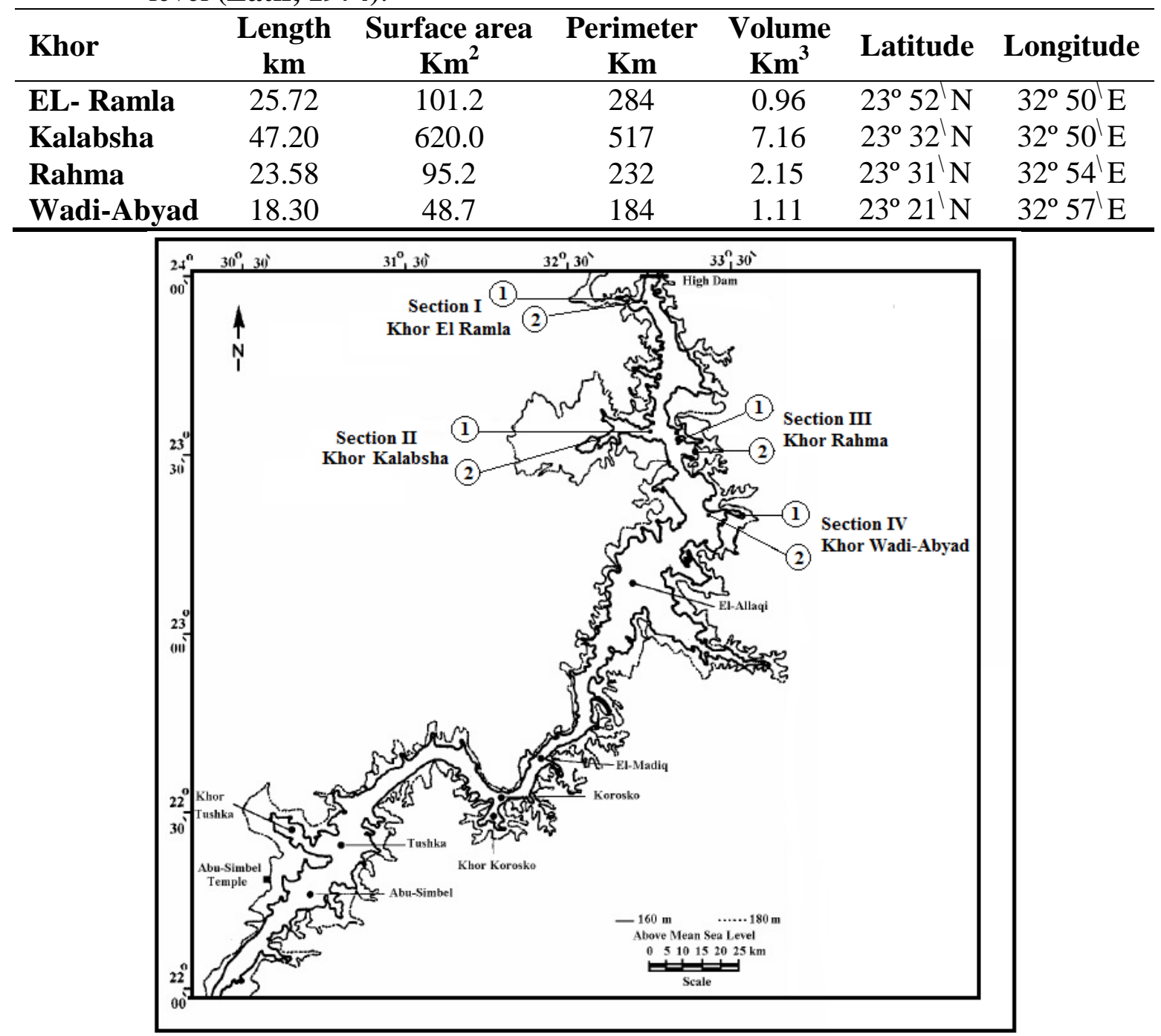

Fig. 1. Sampling sites along the northern khors in Lake Nasser, Egypt

\subsection{Field sampling and Laboratory analysis}

At each khor, 2 sectors were selected to represent the different habitats. The $1^{\text {st }}$ one lies nearby the mainstream, while the $2^{\text {nd }}$ is at the middle of the khor. At each sector, 2 sites were taken for sampling from the different khors; namely, the littoral shallow area that extends down to 6 meters depth and at the offshore deep stations, which are usually located approximately in the middle of the khors (about 20 m). Khors El-Ramla and Kalabsha lie on the western bank of the lake, while Khors Rahma and Wadi-Abyad are located on the eastern side.

Sampling was conducted during a one- year period (2015) on a seasonal basis. Water temperatures, conductivity and $\mathrm{pH}$ were measured by using CRISON Multimeter MM40+ (APHA, 1992). Water transparency was determined by means of a white enameled standard Secchi disc, with a diameter of $20 \mathrm{~cm}$ and dissolved oxygen by an oxygen electrode (Jenway oxygen meter, model 1070 Jenway, Uk) were measured in situ. Water samples were collected 
using the water sampler Van-Dorn Bottle. Water contents $\left(\mathrm{NO}_{2}-\mathrm{N}, \mathrm{NO}_{3}-\mathrm{N}\right.$ and $\left.\mathrm{PO}_{4}-\mathrm{P}\right)$ were determined by methods described in APHA (1992, 1995). For chlorophyll-a concentration, water was filtered through Whatman GF/C glass fibber filter, and subsequently extracted with 95\% methanol. Absorbance was measured spectrophotometrically at 3 different wave lengths $(630,645 \& 663 \mathrm{~nm})$. Chlorophyll-a concentration were calculated according to the method of Marker et al. (1980). In addition, the bottom sediment samples were mechanically analyzed, using the sieving and pipette techniques (Carver, 1971). Determination of organic matter was carried out according to Hanna (1965) and calcium carbonate was measured by using Collin Calcimeter. For the heavy metals, subsamples of the sediments were oven dried at $105^{\circ} \mathrm{C}$ to constant weight and were ground using mortar and pestle. Then, the samples were sieved to $\leq$ $200 \mu \mathrm{m}$. A complete digestion of sediments was done according to the method of Kouadio and Trefry (1987), and $\mathrm{Fe}, \mathrm{Mn}, \mathrm{Zn}$ and $\mathrm{Cu}$ were analyzed by atomic absorption model GBC Savanta AA 901.

\subsection{Collection and treatment of macrobenthic invertebrates}

Duplicate samples of macrobenthic invertebrates were collected at each investigated site using Ponnar grab with an area of $225 \mathrm{~cm}^{2}$. The living material of macrobenthic fauna was immediately separated from the sediments by washing through a metallic sieve with a mesh size of $440 \mu \mathrm{m}$ to sift the samples in the field. The separated species were dried on filter paper and weighed after removing the shells of molluscs, and then the biomass was estimated and expressed as $\mathrm{gm} / \mathrm{m}^{2}$. Afterwards, the samples were fixed with formalin solution at a final concentration of $5 \%$ to be preserved for further microscopic examination. Numerical determination was performed and presented in the form of the number of individuals per square meter (ind. $/ \mathrm{m}^{2}$ ).

Moreover, special treatment was performed on chironomid larvae for accurate identification. The head capsule or entire body was placed in a crucible containing $5-10 \%$ $\mathrm{KOH}$ solution and heated until the muscle tissue was digested. The cleared specimens were rinsed in distilled water, transferred to absolute alcohol and mounted on a slide with its ventral-slips were pressed gently with a lead pencil for better exposure of the parts necessary for identification (Mason, 1973). A total of 128 samples of macrobenthic invertebrates were examined.

For the identification of the aquatic insects, the following references used were: Wirth and Stone (1968), Mason (1973), Hilsenhoff (1975) and Smith and Pritchard (1968). The main references used for molluscs, included that of Demian (1959), Brown (1980), Brown et al. (1984) and Ibrahim et al. (1999). For the identification of oligochaetes, Brinkhurst and Jamieson (1971) and Pennak (1978) were used and furtherly checked by Dr. E.G. Easton (British Museum). Hirudinea were also identified with the kind help of Prof. Dr. N. El-Shamy and Prof. Dr. A. H. Obuid-Allah (Department of Zoology, Assiut University, Assiut).

\subsection{Statistical analysis}

Analysis of variance on SPSS software package (version, 23) (SYSTAT statistical program) was used to test the present data. Pearson correlation coefficient and stepwise multiple regressions were applied to select the affected variables and calculate regression equations. Shannon-Wiener index $(\mathrm{H})$ of general diversity associated with the season was determined by using Shannon Wiener's equation $\mathrm{H}=\Sigma$ pi (ln pi). The evenness index (e) was 
used to measure how event the number of individuals is distributed $\mathrm{e}=\mathrm{H} /$ (Ins). Species richness (S) was used to calculate the number of species during season. Probability value $\leq$ 0.05 was defined as significant throughout the present study, but the value $\geq 0.05$ was defined as non- significant.

\section{Results}

Lake Nasser is characterized by extreme arid conditions with no precipitation and hot summer with a mean value of maximum temperature of $46^{\circ} \mathrm{C}$. The water level of the lake during the present investigation fluctuated between a minimum value of $175.13 \mathrm{~m}$ and a maximum one of $179.97 \mathrm{~m}$ above mean sea level. The increase in water level causes inundation of new lands on both sides of the lake and their extent depends on the slope.

\subsection{Water quality}

Mean annual values and seasonal variations of the main physical, chemical and sediment contents with their standard deviations are reported in Table (2). The khors' water temperature was lower in winter (range: $18.5-23.2{ }^{\circ} \mathrm{C}$ ) and autumn $\left(24.4-25.9{ }^{\circ} \mathrm{C}\right.$ ), compared to spring (range: $25.9-34.5^{\circ} \mathrm{C}$ ) and summer (range: $28.1-30.1{ }^{\circ} \mathrm{C}$ ). Secchi Disc visibilities were recorded to be of relatively high values during the period of this investigation where its highest level was in winter (avg. $4.0 \mathrm{~m}$ ) and autumn (avg. $4.5 \mathrm{~m}$ ). Electrical conductivity (E.C.) was generally of moderate values, with a tendency of somewhat smaller during autumn (ranges: 233.0-253.96 $\mu \mathrm{s} / \mathrm{cm}$ ). This phenomenon is due to the incoming flood from the south that lowers the conductivity due to the precipitation of the suspended matter, leaving the water nearly free of electrical minerals containing ionic salts (Bishai et al., 2000). Electrical conductivity reached its maximum levels in winter (range: $264-283 \mu \mathrm{s} / \mathrm{cm}$ ), coinciding with the falling water temperature. The high values of dissolved oxygen (D.O) recorded during winter $(7.2-10.35 \mathrm{mg} / \mathrm{l})$ and spring $(5.01-9.6 \mathrm{mg} / \mathrm{l})$ may be attributed to the falling of water temperature and photosynthetic activities of phytoplankton, respectively. However, low oxygen content was estimated during summer at most sectors below $10 \mathrm{~m}$ depth, coinciding with its consumption by the decomposition of organic matter by bacteria. Values of hydrogen ion concentration $(\mathrm{pH})$ were always above 7 , indicating slight alkaline water conditions of the khors water. Slight seasonal and vertical fluctuations in $\mathrm{pH}$ were observed; it ranged between 8.0 and 9.37 in the surface water and between 7.8 and 9.2 in the bottom water. The temporal difference in chlorophyll-a concentrations was obvious. Chlorophyll-a concentrations peaked in winter (avg. $8.2 \mathrm{mg} / \mathrm{m}^{3}$ ) and spring (avg. 7.95 $\mathrm{mg} / \mathrm{m}^{3}$ ). The mean values of Chlorophyll-a concentrations during summer and autumn decreased in almost all the investigated sectors without exceeding the average of $6.84 \mathrm{mg} / \mathrm{m}^{3}$.

Generally, the nutrient concentrations $\left(\mathrm{NO}_{2}-\mathrm{N}, \mathrm{NO}_{3}-\mathrm{N}\right.$ and $\left.\mathrm{PO}_{4}-\mathrm{P}_{2}\right)$ showed a wide range of variations with relatively recorded high difference between minimum and maximum levels. Therefore, the highest concentration of $\mathrm{NO}_{2}-\mathrm{N}$ was attained during winter (ranges: $3.171-10.801 \mu \mathrm{g} / \mathrm{l}$ ), compared to a relative decrease in summer (range: $2.454-5.884 \mu \mathrm{g} / \mathrm{l}$ ) and autumn with recorded ranges of $0.463-10.801 . \mu \mathrm{g} / 1$. The maximum values of $\mathrm{NO}_{3}-\mathrm{N}$ were also reached during winter (ranges: 72.055-125.274 $\mu \mathrm{g} / \mathrm{l}$ ). During summer and autumn, $\mathrm{NO}_{3}-\mathrm{N}$ concentrations declined sharply, varying between 8.768 and $47.080 \mu \mathrm{g} / 1$ for the former one and 7.071 and $36.836 \mu \mathrm{g} / 1$ for the latter. High concentrations of $\mathrm{PO}_{4}-\mathrm{P}_{2}$ were detected during spring between khors El-Ramla and Kalabsha (range: $21.190-116.107 \mu \mathrm{g} / \mathrm{l}$ ) and the 
minimum ones were estimated during winter between Khors Rahma and Wadi-Abyad (ranges: 16.365-28.259 $\mu \mathrm{g} / 1$ ).

Grain size analysis revealed that the studied bottom sediment samples in the different khors are mainly composed of silty clayey sand followed by clayey silty sand and clayey sandy silt. The sand fraction formed the main size of the sediments at both the littoral sites (ranges: $27.2-89.8 \%$ ) and at the offshore ones (23.0-77.0\%). Silt and clay fractions were increased with the depth, while sand fraction decreased in the same trend. High level of organic matter was found at both the littoral and offshore sites during spring (ranges: 2.55 $10.85 \%$ ) and summer (ranges: 2.11-11.43\%), accompanied with the flourishing of phytoplankton. Winter and autumn sustained the lowest values of organic matter also coinciding with the high production of macrobenthic invertebrates that feed on it or with the winter convection. Calcium carbonate $\left(\mathrm{CaCO}_{3}\right)$ content of the analyzed bottom sediments ranged between $0.62 \%$ during winter and $30.68 \%$ in summer. The highest concentrations of $\mathrm{CaCO}_{3}$ were estimated during spring and summer. High values were also found in autumn reflecting their gradual accumulation during the previous ones, whereas winter sustained the lowest values coinciding with winter convection.

The concentrations of iron $(\mathrm{Fe})$, manganese $(\mathrm{Mn})$, zinc $(\mathrm{Zn})$ and copper $(\mathrm{Cu})$ in the studied bottom sediments in the northern khors of Lake Nasser are indications that winter has the highest level of Fe and $\mathrm{Mn}$ at both the littoral and offshore sites (ranges: $15362-149448$ ppm and 699.2 - 2005 ppm, respectively). Contrarily, $\mathrm{Zn}$ and $\mathrm{Cu}$ attained their maximum concentrations during summer (ranges: 21.2-29.50 ppm) and in autumn (ranges: 17.84 - 50.13 ppm), respectively.

Table 2. Mean values, standard deviation (SD), minimum and maximum, physical, chemical and biological parameters in the northern khors of Lake Nasser during the investigation period

\begin{tabular}{lllll}
\hline \multirow{2}{*}{ Parameter } & Mean value & \multirow{2}{*}{$\mathrm{SD}$} & \multicolumn{2}{c}{ Ranges } \\
\cline { 5 - 5 } & & & Minimum & Maximum \\
\hline Temperature $\left({ }^{\circ} \mathrm{C}\right)$ & 25.75 & 0.34 & $18.5(\mathrm{Wi})$ & $34.5(\mathrm{Sp})$ \\
Secchi depth $(\mathrm{m})$ & 3.82 & 0.21 & $2.5(\mathrm{Sp})$ & $5.8(\mathrm{Au})$ \\
Electric conductivity $(\mu \mathrm{s} / \mathrm{cm})$ & 246.78 & 4.25 & $230(\mathrm{Au})$ & $318(\mathrm{Wi})$ \\
Dissolved oxygen $(\mathrm{mg} / \mathrm{l})$ & 7.79 & 0.17 & $2.02(\mathrm{Su})$ & $10.35(\mathrm{Wi})$ \\
$\mathrm{pH}$ value & 8.39 & 0.07 & $7.60(\mathrm{Sp})$ & $9.37(\mathrm{Su})$ \\
$\mathrm{NO}_{3}-\mathrm{N}(\mu \mathrm{g} / \mathrm{l})$ & 46.35 & 4.04 & $7.071(\mathrm{Au})$ & $125.274(\mathrm{Wi})$ \\
$\mathrm{NO}_{2}-\mathrm{N}(\mu \mathrm{g} / \mathrm{l})$ & 4.25 & 0.87 & $0.654(\mathrm{Au})$ & $10.804(\mathrm{Au})$ \\
$\mathrm{PO}_{4}-\mathrm{P}_{2}(\mu \mathrm{g} / \mathrm{l})$ & 34.27 & 10.14 & $10.628(\mathrm{Au})$ & $116.107(\mathrm{Sp})$ \\
$\mathrm{Chlorophyll}^{-\mathrm{a}}(\mu \mathrm{g} / \mathrm{l})$ & 6.82 & 3.81 & $2.84(\mathrm{Su})$ & $25.62(\mathrm{Wi})$ \\
$\mathrm{Sand}(\%)$ & 64.40 & 21.65 & 27.20 & 89.80 \\
$\mathrm{Silt}(\%)$ & 22.10 & 18.0 & 5.0 & 62.40 \\
$\mathrm{Clay}(\%)$ & 13.50 & 7.25 & 5.10 & 26.0 \\
Organic matter $(\%)$ & 4.73 & 1.76 & $1.56(\mathrm{Au})$ & $11.43(\mathrm{Su})$ \\
Calcium carbonate $(\%)$ & 6.60 & 4.04 & $0.62(\mathrm{Wi})$ & $29.86(\mathrm{Au})$ \\
Fe $(\mathrm{ppm})$ & 29890 & 16006.5 & $5500(\mathrm{Su})$ & $149448(\mathrm{Wi})$ \\
Mn $(\mathrm{ppm})$ & 326.1 & 198.06 & $77.4(\mathrm{Au})$ & $2004.6(\mathrm{Wi})$ \\
Zn $(\mathrm{ppm})$ & 138.1 & 78.89 & $21.5(\mathrm{Wi})$ & $825.4(\mathrm{Su})$
\end{tabular}




\begin{tabular}{lllll}
$\mathrm{Cu}(\mathrm{ppm})$ & 22.8 & 4.81 & $6.75(\mathrm{Sp})$ & $48.4(\mathrm{Au})$ \\
Total benthos $\left(\mathrm{ind} . \mathrm{m}^{2}\right)$ & 1986 & - & $264(\mathrm{Sp})$ & $7480(\mathrm{Au})$ \\
Total biomass $\left(\mathrm{GFW} / \mathrm{m}^{2}\right)$ & 14.1 & - & $3.3(\mathrm{Sp})$ & $30.12(\mathrm{Au})$ \\
Aquatic insects $\left(\mathrm{ind} . / \mathrm{m}^{2}\right)$ & 1095 & - & $132(\mathrm{Su})$ & $4048(\mathrm{Wi})$ \\
Biomass $\left(\mathrm{GFW} / \mathrm{m}^{2}\right)$ & 4.9 & - & $0.3(\mathrm{Sp})$ & $8.93(\mathrm{Wi})$ \\
Oligochaetes $\left(\mathrm{ind} . / \mathrm{m}^{2}\right)$ & 494 & - & $44(\mathrm{Su})$ & $3080(\mathrm{Wi})$ \\
Biomass $\left(\mathrm{GFW} / \mathrm{m}^{2}\right)$ & 2.5 & - & $0.5(\mathrm{Su})$ & $13.98(\mathrm{Sp})$ \\
Molluscs $\left(\mathrm{ind} . \mathrm{m}^{2}\right)$ & 355 & - & $44(\mathrm{Wi})$ & $1804(\mathrm{Sp})$ \\
Biomass $\left(\mathrm{GFW} / \mathrm{m}^{2}\right)$ & 6.4 & - & $0.2(\mathrm{Sp})$ & $14.3(\mathrm{Sp})$ \\
Rare fauna $\left(\mathrm{ind} . / \mathrm{m}^{2}\right)$ & 42 & - & $11(\mathrm{Wi})$ & $88(\mathrm{Sp})$ \\
Biomass $\left(\mathrm{GFW} / \mathrm{m}^{2}\right)$ & 0.3 & - & $0.3(\mathrm{Wi})$ & $0.6(\mathrm{Sp})$ \\
\hline
\end{tabular}

Seasons (in parentheses); Wi: winter, Sp: spring, Su: summer, Au: autumn, SD: standard deviation.

\subsection{Macrobenthic invertebrates}

Twenty- seven taxa represented the macrobenthic invertebrate community at the littoral sites of the northern khors of Lake Nasser (Table 3). Sixteen of those taxa were aquatic Insecta (10 larvae of Chironomidae, 3 nymphs of Odonata, 1 adult Corixidae and 1 unknown nymph of Ephemeroptera and larvae of Trichoptera), 5 related to Anneliela (3 Oligochaetae and 2 Hirudinea), 5 to Mollusca and 1 Decapoda. The offshore sites harboured only 8 taxa; namely, the 3 oligochaetes, 1 chironomid larvae, 1 corixidian, 1 unknown nymph of ephemeropteran, 1trichopteran larvae and 1 molluscs. Therefore, mean annual values of the total counts at the littoral sites reached up to $1986 \mathrm{ind} . / \mathrm{m}^{2}$, with a biomass of $14.1 \mathrm{GFW} / \mathrm{m}^{2}$, compared to 448 ind.$/ \mathrm{m}^{2}$ and a biomass of $6.0 \mathrm{GFW} / \mathrm{m}^{2}$ recorded at the offshore ones. The abundance of the khors macrobenthic invertebrates (Fig. 2) varied considerably among seasons with remarkable differences between each other khor. At the littoral sites of Khors ElRamla and Kalabsha, the densities of macrobenthic invertebrate assemblages were of relatively higher values than those estimated at Khors Rahma and Wadi Abyad. Aquatic insects prevailed at all the khors followed by oligochaetes and molluscs.

It was noticed that, the seasonal periodicity in the distribution of the khors macrobenthic invertebrates presented in Fig. (3) revealed that, winter and autumn had the highest standing crop, particularly at the littoral sites of sector II and sector I of Khor El-Ramla that harboured 6908 ind. $/ \mathrm{m}^{2}$, with a biomass of $17.9 \mathrm{GFW} / \mathrm{m}^{2}$ and $7480 \mathrm{ind} . / \mathrm{m}^{2}$ with a biomass of 30.1 $\mathrm{GFW} / \mathrm{m}^{2}$, respectively. At the offshore ones (Fig. 3), the total counts of macrobenthic invertebrates remained relatively low during winter and spring, though showing a tendency of a pronounced increase at sector I of Khor Wadi-Abyad $\left(1760 \mathrm{ind} . / \mathrm{m}^{2}\right.$ with $\left.28.8 \mathrm{GFW} / \mathrm{m}^{2}\right)$ and at sector I of Khor Rahma (1496 ind. $/ \mathrm{m}^{2}$ with $12.8 \mathrm{GFW} / \mathrm{m}^{2}$ ) during summer and autumn , respectively.

With respect to the different groups of aquatic insects khors, chironomid larvae constituted the main group in numerical abundance since they constituted about 27.1 and $49.1 \%$ (avg. 538 larvae/ $\mathrm{m}^{2}$ ) of the total benthos and aquatic insects, respectively. Chironomid larvae exhibited their maximum abundance at Khor El-Ramla (avg. 1397 larvae/m² with 1.4 $\mathrm{GFW} / \mathrm{m}^{2}$ ), followed by a gradual decrease till Khor Wadi-Abyad (avg.77 larvae $/ \mathrm{m}^{2}$ with 0.05 GFW $/ \mathrm{m}^{2}$ ) (Fig. 4). Their peaks were reached during winter and autumn (Fig. 5) due to the dominance of Dicrotiendipes modestus, which contributed about 17.0 and $34.6 \%$ from the total aquatic insects and chironomid larvae, respectively. On the other hand, 4 species of 
those larvae appeared more or less dominant, while the remaining ones were registered once. Besides, their pupae were scarcely recorded at the littoral sites (ann. avg.: 11- 66 pupae $/ \mathrm{m}^{2}$ with a biomass: $0.3-0.5 \mathrm{GFW} / \mathrm{m}^{2}$ )

The distribution of odonates nymph was confined to the littoral sites (Fig. 4). Although their annual average numbers mounted to 127 nymphs $/ \mathrm{m}^{2}$, constituting numerically about $11.6 \%$ of the total insects, yet their biomass increased to $60.4 \%$ of the total weights (avg. 2.9 $\mathrm{GFW} / \mathrm{m}^{2}$ ) due to their big size. The maximum abundance of odonates nymphs were observed in Khor Kalabsha (avg. 237 nymphs $/ \mathrm{m}^{2}$ with $5.4 \mathrm{GFW} / \mathrm{m}^{2}$ ). The order include few species among which Perithemis sp (Family: Corduliidae) and Libelulia sp. (Family: Libelullidae) which belong to the suborder: Anisoptera and Pseudagrion niloticum Dumont (Family: Coenagrionidae) of the suborder: Zygoptera were identified.

Nymphs of Ephemeroptera constituted about $14.2 \%$ by the number of total insects (avg. 156 nymphs $/ \mathrm{m}^{2}$ ) and $6.3 \%$ of their weights (avg. $0.3 \mathrm{GFW} / \mathrm{m}^{2}$ ). At the littoral sites (Fig. 4), their maximum abundance recorded at sector I of Khor Kalabsha (avg. 363 nymphs $/ \mathrm{m}^{2} \& 0.7$ GFW $/ \mathrm{m}^{2}$ ) with a peak during autumn (1408 nymphs $/ \mathrm{m}^{2} \& 2.6 \mathrm{GFW} / \mathrm{m}^{2}$ ) (Fig. 4). These nymphs at the offshore sites were scarcely recorded or completely missed.

Adult Corixidae constituted about $19.7 \%$ by the number of total insects (avg. 216 insect $/ \mathrm{m}^{2}$ ) and $7.6 \%$ of their weights (avg. $0.4 \mathrm{GFW} / \mathrm{m}^{2}$ ). Its maximum abundance was mainly confined to the littoral sites of Khor Wadi Abyad during winter (Fig. 4) (avg. $3080 \mathrm{insect} / \mathrm{m}^{2}$ \& $1.2 \mathrm{GFW} / \mathrm{m}^{2}$ ). The family Corixidae was represented by 1 species; namely Micronecta plicula.

Larvae of the order Trichoptera appeared mostly during summer and autumn at the sites lying between Khor El-Ramla and Khor Kalabsha (Fig. 4). At the offshore sites, it appeared once at sector II of Khor El-Ramla (avg. 33 larvae/ $\mathrm{m}^{2} \& 0.4 \mathrm{GFW} / \mathrm{m}^{2}$ ).

Oligochaetes represented the second important bottom dwellers inhabiting the littoral sites. They constituted respectively about $24.9 \%$ and $17.7 \%$ by numbers and biomass of the total macrobenthic invertebrates there (avg. $494 \mathrm{ind} . / \mathrm{m}^{2}$ with $2.5 \mathrm{GFW} / \mathrm{m}^{2}$ ). Oligochaetes reached their maximum abundance at Khor El-Ramla (avg. 1100 ind. $/ \mathrm{m}^{2}$ with $3.3 \mathrm{GFW} / \mathrm{m}^{2}$ ) (Fig. 2). Their occurrence at the offshore sites was less abundant, attaining annual average number of $130 \mathrm{ind} . / \mathrm{m}^{2}$ with $1.9 \mathrm{GFW} / \mathrm{m}^{2}$. The class was represented by 3 species belonging to the family Tubificidae; namely, Limnodrilus udekemianus Clap., L. hoffmeisteri Clap and Branchiura Sowerbyi Bed. Khor El-Ramla and sector II of Khor Kalabsha harbored the highest density during autumn (avg. 5060 ind. $/ \mathrm{m}^{2}$ with $25.1 \mathrm{GFW} / \mathrm{m}^{2}$ and $1628 \mathrm{ind} . / \mathrm{m}^{2}$ with $7.3 \mathrm{GFW} / \mathrm{m}^{2}$, respectively) (Fig. 6), produced by the increased numbers of L. hoffmeisteri, followed by L. udekemianus. Another increasing values of oligocheates were also recognized at sector II of the same two khors during winter that mainly consisted of L. udekemianus. At the offshore sites, they were less abundant or completely disappeared throughout winter and spring, but appeared more or less common during summer and autumn due to the increased density of L. hoffmeisteri, L. udekemianus and B. sowerbyi, respectively.

Mollusca represented the third important bottom dwellers inhabiting the littoral sites of the northern khors of Lake Nasser. They respectively constituted about $17.9 \%$ and $45.4 \%$ by numbers and biomass of the total benthos there (avg. 355 gastropods $/ \mathrm{m}^{2}$ with $6.2 \mathrm{GFW} / \mathrm{m}^{2}$ ). Their maximum abundance (Fig. 2) was recorded at sector II of Khor Kalabsha (avg. 902 gastropods $/ \mathrm{m}^{2}$ and $12.4 \mathrm{GFW} / \mathrm{m}^{2}$ ) compared to that recorded at sector I of Khor Rahma (avg. 
165 gastropods $/ \mathrm{m}^{2}$ with $3.4 \mathrm{GFW} / \mathrm{m}^{2}$ ). At the offshore sites, their occurrence was very rare. The molluscs recorded included 4 gastropods belonging to 4 families; namely, Valvata nilotica Jickeli, Physa acutu Darparnaud, Bulinus truncatus Audouin and Melonoides tuberculata Muller and 1 Bivalvia that belongs to 1 family; namely Spharium (Mussculium) hartmanni Jickeli. Two peaks of abundance were recorded in Fig. (7). The $1^{\text {st }}$ one was during spring (avg. 407 gastropods $/ \mathrm{m}^{2}$ and $4.7 \mathrm{GFW} / \mathrm{m}^{2}$ ), particularly at Khors El-Ramla and Kalabsha due to the increased density of $V$. nilotica and less density of B. truncatus. The $2^{\text {nd }}$ peak was recorded during summer due to the dominance of $M$. tuberculata in Khor WadiAbyad.

Other species of rare occurrence were recorded in the northern khors of Lake Nasser, including 2 species of class Hirudinea, namely; Helobdella conifera Moore which belongs to the family Glossiphoniidae and Barbronia assiuti (Hussein \& El-Shimy, 1982) which belongs to the family Erpobellidae_and the crustacean Cardina nilotica Roux. They constituted collectively about $2.2 \%$ of the total number of macrobenthic invertebrates with an annual average of $42 \mathrm{ind} . / \mathrm{m}^{2}$ and $0.3 \mathrm{GFW} / \mathrm{m}^{2}$.

Table 3. Macrobenthic invertebrate species recorded in the northern khors of Lake Nasser and their presence contribution $(\%)$

\begin{tabular}{|c|c|c|c|}
\hline \multirow{2}{*}{ Species } & \multirow{2}{*}{ Author } & \multicolumn{2}{|c|}{$\%$} \\
\hline & & Littoral & Offshore \\
\hline Dicrotiendipes modestus & Kieffer & 9.3 & 0 \\
\hline Procladius & Skuse & 6.1 & 4.2 \\
\hline Microtiendipes & Kieffer & 5.2 & 0 \\
\hline Ablabesmyia & Johannsen & 2.0 & 0 \\
\hline Cryptochironomus & Kieffer & 1.9 & 0 \\
\hline Tanytarsus & Van der Wulp & 1.1 & 0 \\
\hline Clinotanypus & Kieffer & 0.7 & 0 \\
\hline Polypedilum & Kieffer & 0.2 & 0 \\
\hline Chironomus & Meigen & 0.3 & 0 \\
\hline Circotopus sudanicus & Freeman & 0.3 & 0 \\
\hline Pupae of Chironomidae & & 0.8 & 0 \\
\hline Libelulla & Linnaeus & 1.1 & 0 \\
\hline Perithemis & Hagen & 1.1 & 0 \\
\hline Pseudagrion niloticum & Dumont & 4.2 & 0 \\
\hline Micronecta plicuta & & 10.9 & 0.7 \\
\hline Nymph of Ephemeroptera & & 7.9 & 10.7 \\
\hline Larvae of Trichoptera & & 2.1 & 0.9 \\
\hline Limnodrilus udekemianus & Claparede & 15.8 & 33.4 \\
\hline Limnodrilus hoffmeisteri & Claparede & 8.0 & 11.7 \\
\hline Branchiura sowerbyi & Beddard & 1.1 & 32.2 \\
\hline Melanoides tuberculate & Muller & 5.5 & 0 \\
\hline Bulinus truncates & Audouin & 4.9 & 0 \\
\hline Valvata nilotica & Jickeli & 4.2 & 6.1 \\
\hline Physa acuta & Draparnaud & 3.2 & 0 \\
\hline Sphearium hartmanni & Jickli & 0.1 & 0 \\
\hline Cardina nilotica & Roux & 1.2 & 0 \\
\hline Helobdella conifer & Moore & 0.7 & 0 \\
\hline Barbronia assuti & Hussein \& El-Shimy, 1982 & 0.1 & 0 \\
\hline
\end{tabular}



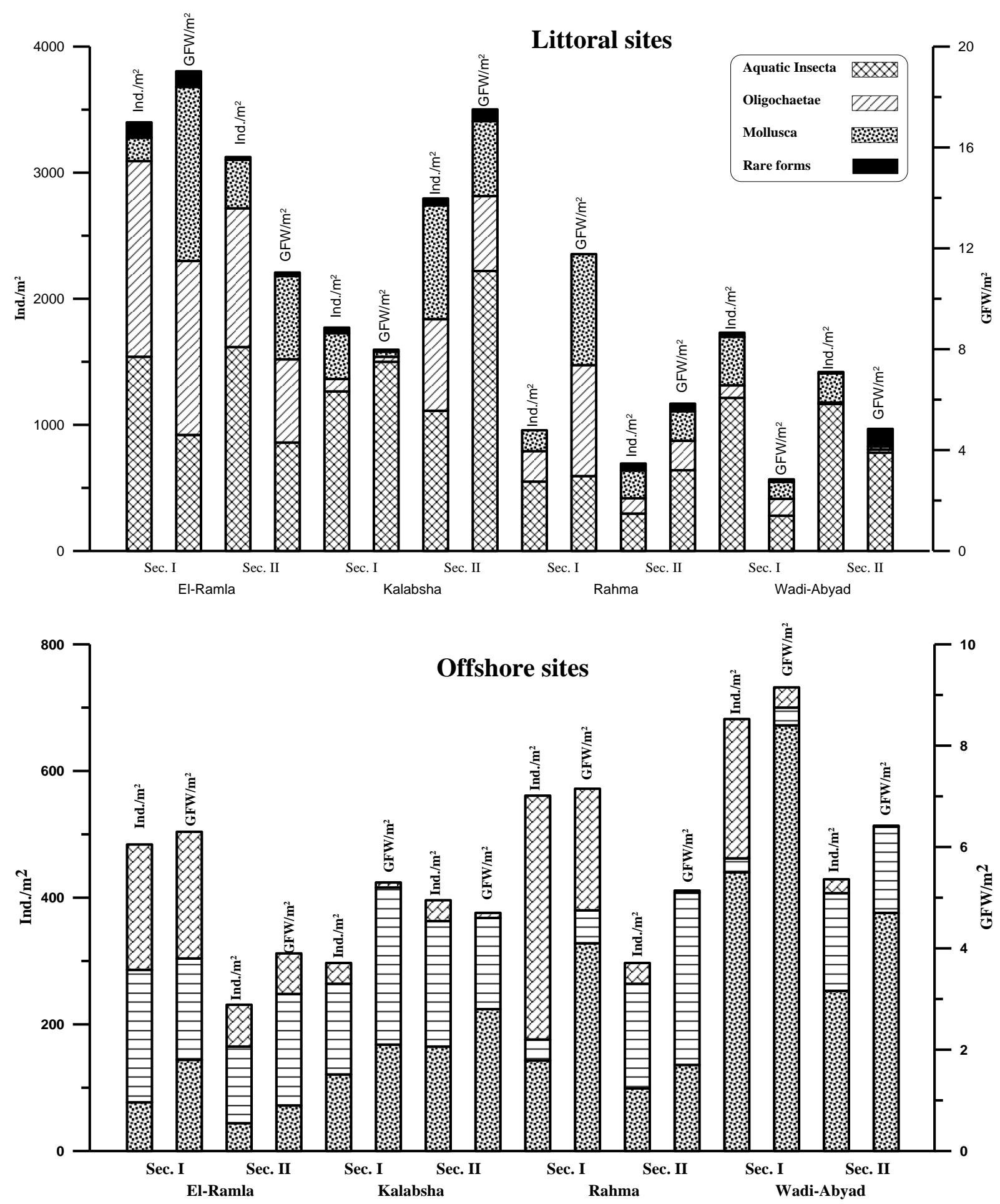

Fig. 2. Annual average density and biomass of the macrobenthic invertebrates (ind. $/ \mathrm{m}^{2} \&$ $\mathrm{GFW} / \mathrm{m}^{2}$ ) recorded in the northern khors of Lake Nasser (Wahab et al., 2018) 
Littoral sites
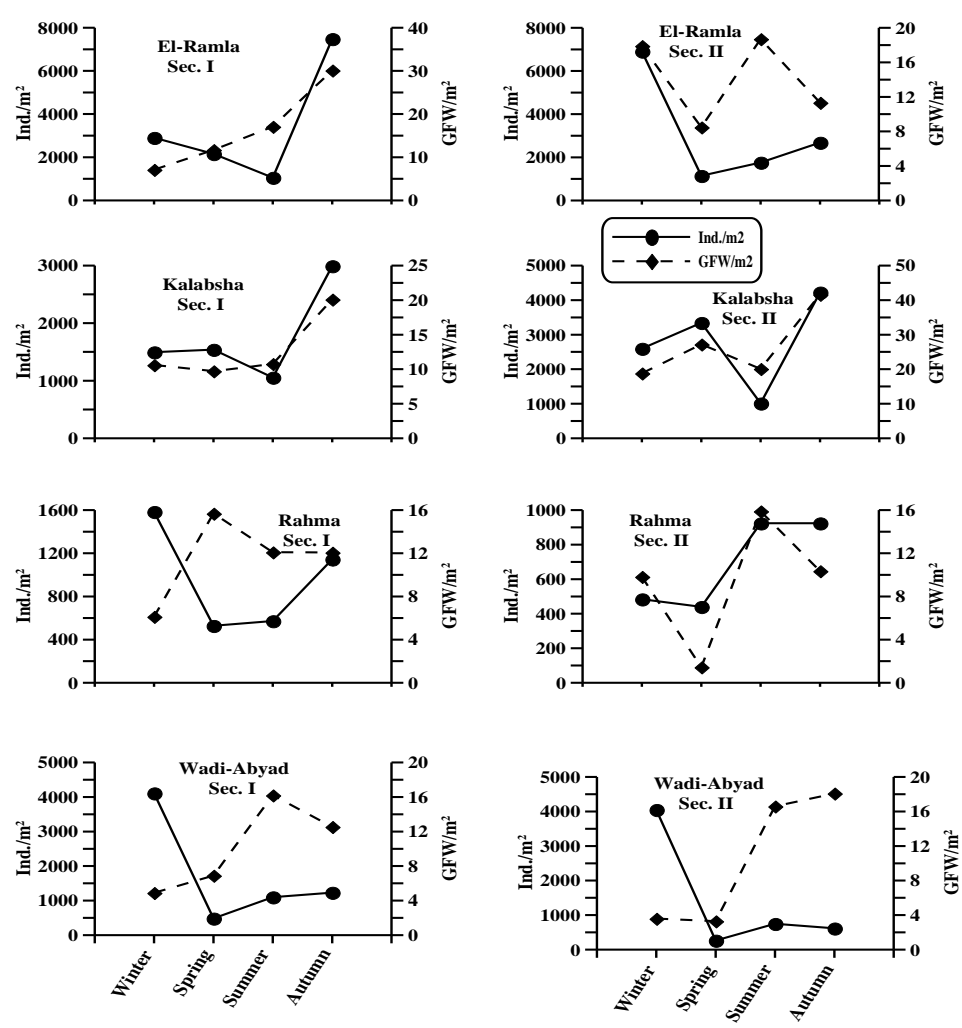

\section{Offshore sites}
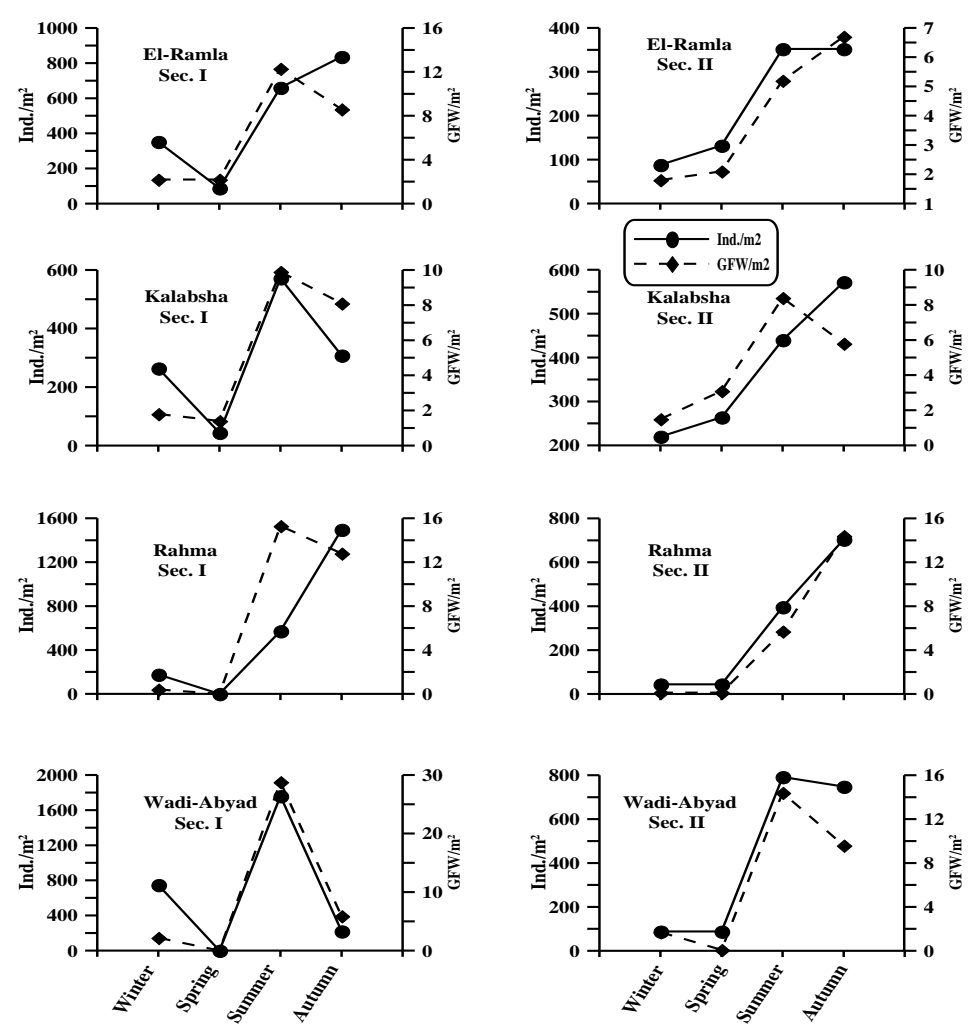

Fig. 3. Seasonal variations of macrobenthic invertebrates (Ind. $/ \mathrm{m}^{2}$ and $\left.\mathrm{GFW} / \mathrm{m}^{2}\right)$ recorded in the northern khors of Lake Nasser 

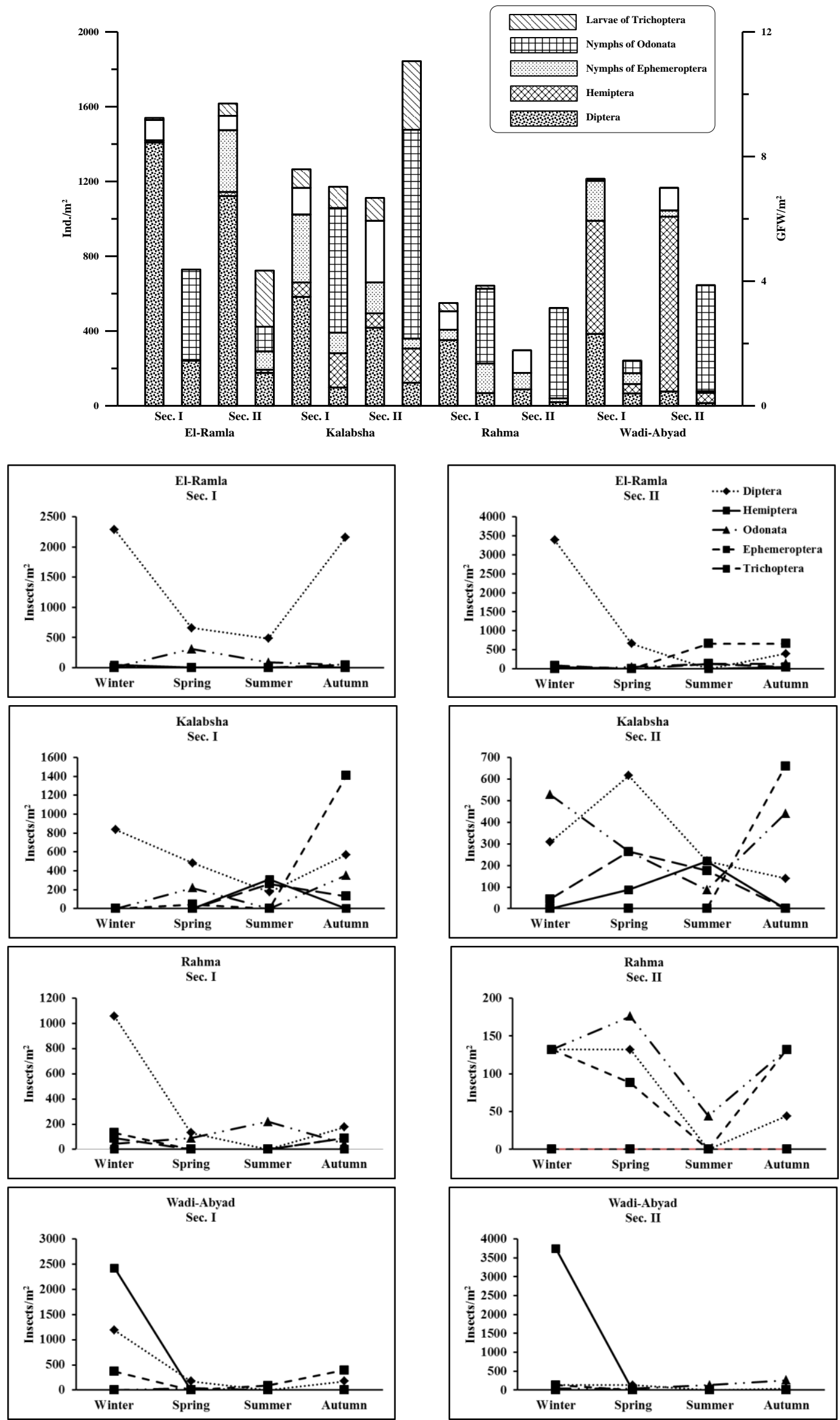

Fig. 4. Distribution and seasonal variations of aquatic insecta (insects $/ \mathrm{m}^{2}$ ) recorded at the littoral sites of the northern khors of lake Nasser 

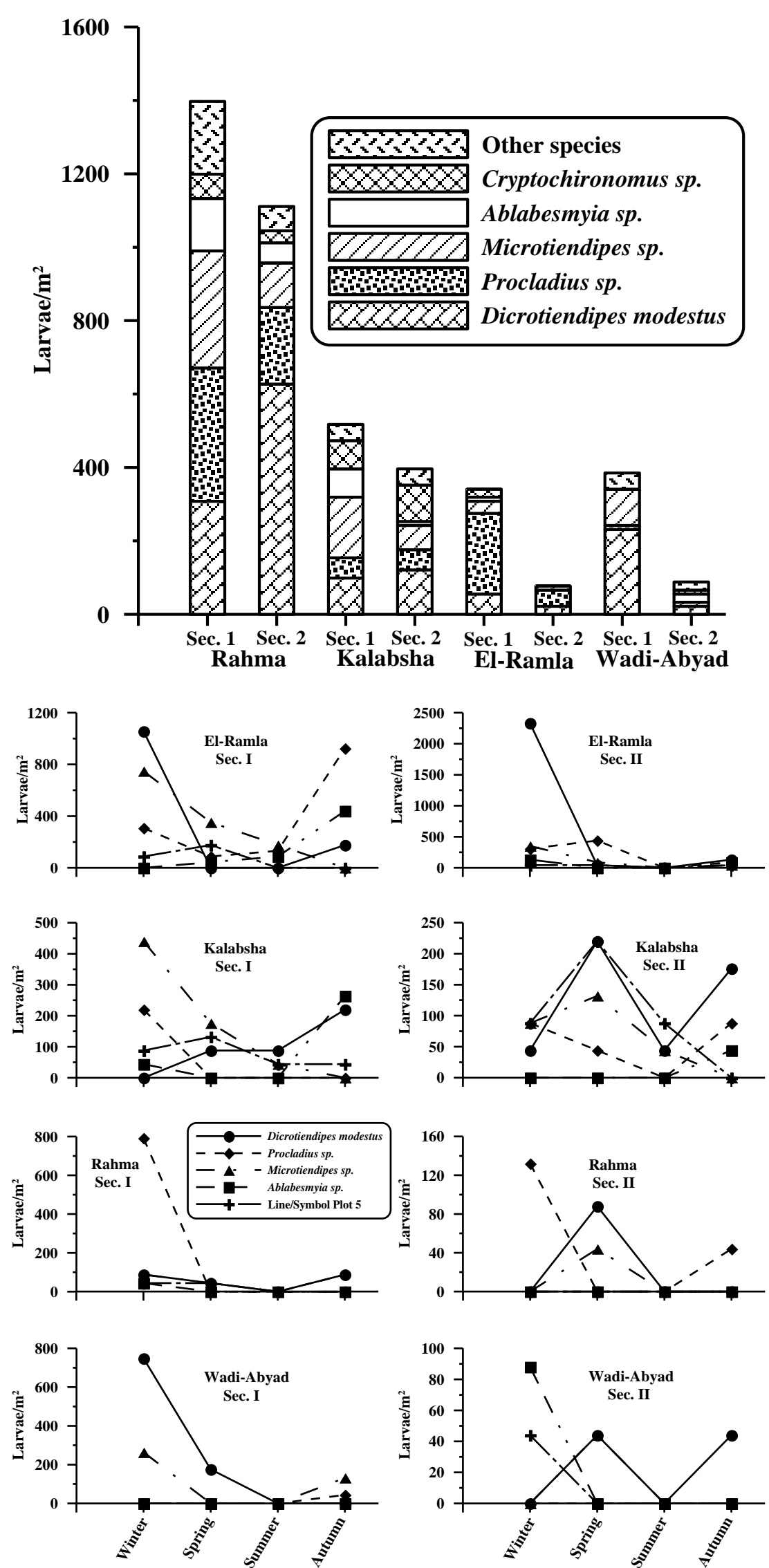

Fig. 5. Distribution and seasonal variations of chironomid larvae (larvae $/ \mathrm{m}^{2}$ ) recorded at the littoral sites of the northern khors of Lake Nasser 

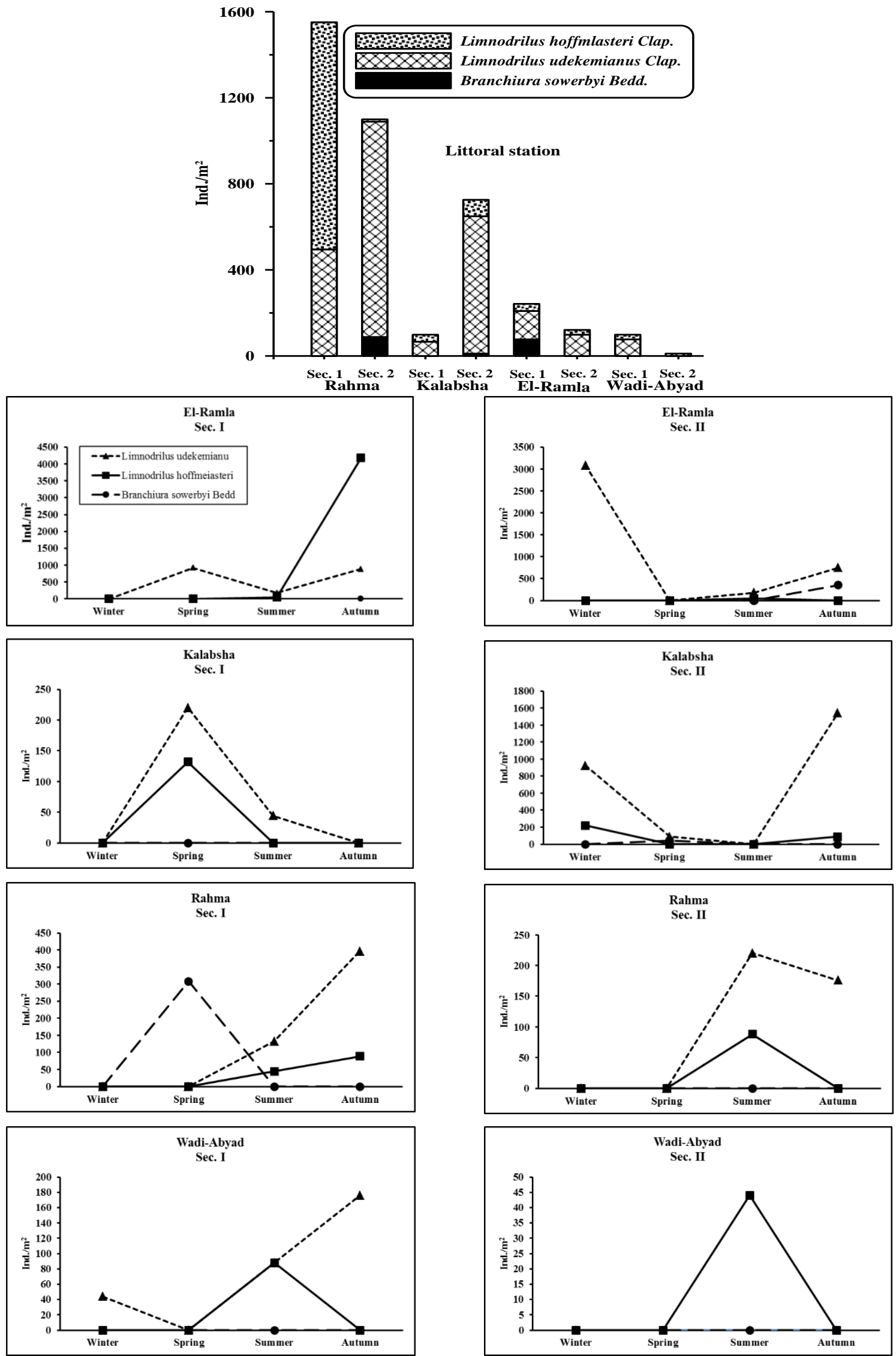

Fig. 6. Distribution and seasonal variations of Oligochaetae $\left(\mathrm{Ind} . / \mathrm{m}^{2}\right)$ recorded at the littoral sites of the northern khors of Lake Nasser 

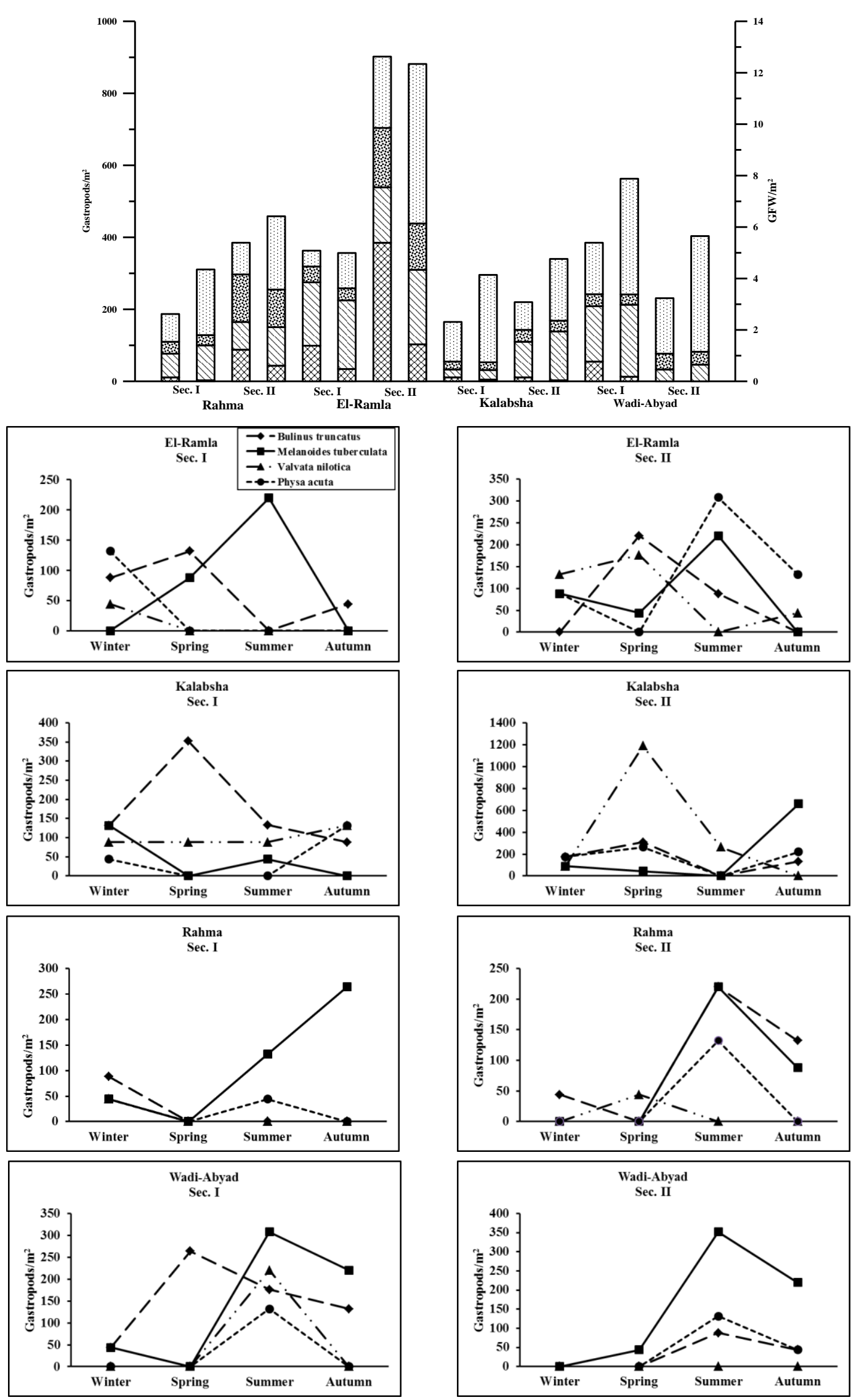

Fig. 7. Distribution and seasonal variations of Mollusca (gastropods $/ \mathrm{m}^{2} \& \mathrm{GFW} / \mathrm{m}^{2}$ ) recorded at the littoral sites of the northern khors of Lake Nasser 


\section{DISCUSSION}

Man-made lakes, similar to other surface water ecosystems, provide a wide array of benefits for people, including water provision, irrigation, flood control, fisheries and other forms of recreation. In Africa, four of such lakes, such as Viz Volta (Ghana), Kariba (Zimbabwe), Kainji (Nigeria) and Nasser (Egypt), each of which exceeds $1000 \mathrm{~km}^{2}$ in area.

The construction of the Aswan High Dam during the period 1959 - 1969, resulted in the creation of the second largest man-made lake in Africa. It's total surface area is about 6276 $\mathrm{Km}^{2}$ at the final storage level of $183 \mathrm{~m}$ above mean sea level, of which $83 \%$ lies in Egypt and the rest in Sudan. Lake Nasser possesses numerous side flooded areas, usually referred to as "khors" (85 khor), constituting about $76 \%$ of its total area.

Khors El-Ramla, Kalabsha, Rahma and Wadi Abyad, the items of the present investigation, constitute collectively about $41.4 \%$ of the total surface area of the most thirteen important khors that lie in Lake Nasser, whereas the surface area of Khor Kalabsha alone represents about $10 \%\left(620 \mathrm{~km}^{2}\right)$ of the total surface area of the lake.

Macrobenthic invertebrates related to aquatic insects, annelids, molluscs and crustaceans were commonly detectedin Lake Nasser (Iskaros, 1988, 1993; Fishar, 1995; Iskaros \& Dardir, 2010; Mohamed, 2018; Wahab et al., 2018). These groups dominated the Zoobenthos community during the period of the present investigation. A change of any of these groups was reflected in the total abundance of the macroberthic invertebrates. Their qualities and quantities are largely influenced by a number of environmental factors (Angradi et al., 2006; Jiang et al., 2010), including biotic and abiotic conditions. Moreover, they are affected by a complex inter-relationship between these conditions. The substrate status is also of a great importance for regulating habitat complexity, food availability and protection against predators. According to Hepp et al. (2012), the different substrate types can also affect the accumulation of organic matter on the lake bed. At the littoral zone of the northern khors of Lake Nasser, relative densities of sand (avg. 64.4\%), silt (avg. 22.1\%) and clay (avg. $13.5 \%$ ), forming the main bottom sediment components, together with submerged macrophytes represented favorite conditions of the existence of multiple macrobenthic invertebrates taxa such as the case of Khor El-Ramla and Khor Kalabsha compared to Khor Rahma which was characterized by little or vegetation-free bottom zone during the present investigation (Fig. 2). Hanna (1995) reported that molluscs and chironomid larvae prefer macrophytes to avoid predators and to feed on epiphytic microorganisms. Those of hirudineas live close to the former group to use them as a source of nourishment (Pennak, 1978). Besides, Fisher and Williams (2006) found that the Nile molluscs are typical populations of the weedy and mud depositing habitats, whereas oligochaetes can survive in soft sediments such as the case of the current study. In this respect, Silva et al. (2014) observed that the environmental and spatial factors may act separately in structuring macrobenthic invertebrate assemblages.

The organic matter in the sediment provides an indication of the amount of setting on the bottom from the water column, and it is used as index of those available for the benthic community (Byers et al., 1978). The highest concentration of organic matter in the northern khors of Lake Nasser were estimated during spring and Summer (ranges: $2.11-11.43 \%$ ) accompanied with the flourishing of phytoplankton, whereas winter and autumn sustained the 
lowest values, coinciding also with the high production of macrobenthic invertebrates that feed on it or with winter convection. Therefore, a significant correlation stands for the abundance measured as total count and biomass of such biota with the sediment contents of organic matter (Table 6). Furthermore, the stepwise multiple regression analysis (Table 8) indicates that organic matter was the only factor that affects oligochaetes. abundance and distribution in the eight investigated sites. Died phytoplankton and zooplankton cells deposited on the bottom of tropic lakes constitute the major food items for the macrobenthic invertebrates. In this context, the importance of the availability of food supply and the physicchemical properties of the sediments were confirmed for the development of macrobenthic invertebrates in freshwater habitats (Brown, 1980).

Encrusting organisms were considered the main source of accumulating carbonates in the sediments of the Nile and Lake Nasser (El-Dardir, 1994; Frahat, 2010). The relatively high contents of $\mathrm{CaCO}_{3}$ throughout spring, summer and autumn (range: $1.06-30.68 \%$ ) probably enhanced the development of macrobenthic fauna in the northern khors of Lake Nasser. Thus, this can explain the significant correlation that stands for the total counts of the molluscs and $\mathrm{CaCO}_{3}$ (Tables 5, 6 \& 8). These results clearly indicate that $\mathrm{CaCO}_{3}$ is of marked importance for the enhancement of the lake macrobenthic invertebrates. Additionally, Ali $\boldsymbol{e t}$ al. (2007) found that the abundance of oligochaetes and molluscs was driven by $\mathrm{Ca}^{2+}$ contents.

Bioactive metals play an important role in the metabolism, and thus in physiology and pathology of fish. Metals such as $\mathrm{Mn}, \mathrm{Zn}$ and $\mathrm{Cu}$ function as a cofactor in several enzyme systems, while $\mathrm{Fe}$ is directly involved with hemoglobin formation in fish blood as well as in chironomid larvae known as blood worms (Bury \& Grosell, 2003). However, these trace elements in the present study had a less influence on the distribution of the macrobenthic invertebrates recorded in the northern khors, except for the indirect effect when the analyzed $\mathrm{Cu}$ displayed significant positive correlation with organic matter amount (Table 6) favoring its adsorption to the organic matter as it was reported in Aswan Reservoir (El-Dardir, 1995).

The annual increase in the water level in Lake Nasser prevails during the period of August - December, and this subsequently increases the total area of the lake, with inundation of new marginal areas besides khors. The maximum water level was attained between November and January, while the minimum was recorded in July; before the next flood. The extension of shallow water in lakes is likely to increase its productivity (Welch, 1952). Thus, in the northern khors of Lake Nasser, macrobenthic invertebrates showed similar trends, reaching their peaks during autumn and winter (Fig. 3) along with the increased areas of the shallower lake margins, as it was also observed in the studies of Iskaros $(\mathbf{1 9 8 8 , 1 9 9 3 ) .}$

In the present study, transparency was determined with the highest values in winter and autumn (ranges: $3.5-5.8 \mathrm{~m}$ ), compared to spring and summer (ranges: $2.5-4.5 \mathrm{~m}$ ). Two main factors affect the degree of water transparency in Lake Nasser (Entz, 1974); namely, alloctonic inorganic silt, mud of riverine origin, and autochtonic suspended organic matter (plankton \& detritus). Entz (1973) pointed out that most of the silt introduced with the flood water is sedimented in Lake Nubia, while only a limited amount reaches the southern sector of Lake Nasser. Similarly, Zaghloul (1985) and Iskaros (1993) mentioned that, the northern part of Lake Nasser with its khors showed the highest transparency values, particularly during autumn and winter, associated with the introduction of flood turbid water in the southern part 
of the lake. While, the lowest values appeared in spring and summer due to the blooming of phytoplankton. The latter author concluded that, the increase density of zooplankton in Khor Kalabsha during winter and autumn parallelled with the increased transparency enables good nourishment of chironomid larvae, which thus appeared more abundant during this period in the present investigation.

The lowest and the highest values of E.C. were estimated during autumn (ranges: 230 $238 \mu \mathrm{s} / \mathrm{cm}$ ) and winter (ranges: $261-318 \mu \mathrm{s} / \mathrm{cm}$ ), respectively. The African lakes were classified by Talling and Talling (1965) according to their conductivity into three classes. Lake Nasser belongs to the $1^{\text {st }}$ class with low conductivity that is less than $60 \mu \mathrm{s} / \mathrm{cm}$. Mageed and Heikel (2006) explained that the low conductivity of the lake water during the flood period is due to the low water conductivity of the flooded Blue Nile which contributes about 84\% of the Nile flood. Entz (1978) illustrated that E.C. is an important factor affecting on the emergency of chironomid larvae. The observed dependence on conductivity showed a significant effect of this factor in the construction of macrobenthic invertebrate assemblages (Table 6).

During winter, summer and autumn, the water column in the different khors was almost isothermic, probably because of its moderate depth (maximum $20 \mathrm{~m}$ ). However, due to the increased water temperature during spring, the difference between surface and bottom waters became prominent only at some sectors (ranges: $6.5-8.5^{\circ} \mathrm{C}$ ). Consequently,from the correlation coefficient presented in Table (6), the aquatic insects and oligochaetes reacted negatively to water temperature. Furthermore, the chironomid larvae inhabiting the littoral sites flourished well in winter and autumn (Fig. 5), concuring with the findings of Iskaros (1988, 1993) in Lake Nasser and Iskaros et al. (2011) in Aswan Reservoir. Conversely, ElDuweini and Ghabbour (1963) regarding oligochaetes assessed that the variations of water temperature are not a determining factor for their seasonal distribution. In addition, Pennak (1978) suggested that, although temperature is not usually a limiting factor it often determines the relative abundance of oligochaetes. Moreover, the number of molluscs inhabiting the littoral sites (Fig. 7) reached their peaks during spring and summer. This is mainly related to the increased fecundity of individuals along with the increase in water temperature, noting that their egg sacs were observed throughout the four seasons with high production in spring and summer as previously illustrated in the investigation of Iskaros (1993).

According to Payne (1986), the oxygen budget in deep lakes depends on a complex of processes entailing oxygen from the atmosphere; oxygen produced by the phytoplankton during photosynthesis, respiration of aquatic biota and oxidation of organic matter. The present result revealed that the khors water was well oxygenated from surface to bottom during all different seasons, except that low oxygen content was estimated during summer at most sectors below $10 \mathrm{~m}$ depth. In the present study, the amount of dissolved oxygen was positively controlling the molluscs density (Table 6). In this regard, Brown (1980) reported that the oxygen is probably the princible limiting factor concerning the snail distribution in Africa.

The $\mathrm{pH}$ values in the different khors were always on the alkaline side at narrow range with maximum values of 9.2 and 9.37 recorded at 10 and $20 \mathrm{~m}$ water layers and surface water layer of sector I of Khor Rahma and sector I of Khor Wadi-Abyad during spring and summer, respectively. Iskaros and El-Otify (2013) recorded the $\mathrm{pH}$ values in Aswan Reservoir 
between a minimum of 7.34 during winter and maximum of 7.95 in spring. They found that the increased density of macrobenthic invertebrates was usually accompanied with the increased $\mathrm{pH}$ values. However, in the present study, the high $\mathrm{pH}$ values together with the increased water temperature during spring and summer corresponded to a sharp decrease in the density of macrobenthic invertebrates, and in particular Khors Rahma and Wadi-Abyad. Thus, a strong negative significant correlation appeared between $\mathrm{pH}$ values and aquatic insects and oligochaetes (Table 6). According to Wurts (2003), ammonia-nitrogen $\left(\mathrm{NH}_{3}-\mathrm{N}\right)$ has a more toxic form to aquatic life at high $\mathrm{pH}$ and a less toxic form at low $\mathrm{pH}$ un-ionized ammonia $\left(\mathrm{NH}_{3}\right)$ and ionized ammonia $\left(\mathrm{NH}_{4}^{+}\right)$, respectively. In addition, ammonia toxicity increases as temperature rises. The afore- mentioned author added that, the $\mathrm{pH}$ values together with $\mathrm{NH}_{3}-\mathrm{N}$ were the most influential abiotic parameters dicating the pattern of seasonal periodicity of the macrobenthic invertebrates.

The maximum values of chlorophyll-a were estimated during winter and spring, particularly in the middle and bottom water layers, compared to summer and autumn. The increase of macrobenthic invertebrates during winter and autumn is generally in concomitant with a parallel increase in phytoplankton density as illustrated by Hussian et al. (2015). This was emphasized by the dependence of benthic fauna on chlorophyll-a concentration (Table 6). Chlorophyll-a is an index of photoautotrophic biomass related to primary production of reservoir that reflects water quality as well as the net standing stock of phytoplankton growth and loss by grazing processes of macrobenthic invertebrates groups (Mason, 1973; Brinkhurst \& Jamieson, 1971; Chellappa et al., 2009).

The nutrients concentrations $\left(\mathrm{NO}_{2}-\mathrm{N}, \mathrm{NO}_{3}-\mathrm{N}\right.$ and $\left.\mathrm{PO}_{4}-\mathrm{P}_{2}\right)$ (Table 2) generally showed wide range of variations with relatively recorded high difference between minimum and maximum levels. The variations reflected the seasonal development of the dissolved inorganic fractions (nitrogen and phosphores). The maximum concentrations of $\mathrm{NO}_{2}-\mathrm{N}$ were recorded during winter and spring (ranges: 3.217-10.102 $\mu \mathrm{g} / \mathrm{l}$ ), while the lowest values appeared in summer and autumn (ranges: 0.463-5.884 $\mu \mathrm{g} / \mathrm{l}$ ). On the other hand, $\mathrm{NO}_{3}-\mathrm{N}$ and $\mathrm{PO}_{4}-\mathrm{P}_{2}$ showed a reverse seasonal trend, where the first components reached its maximum concentrations in winter (ranges: $72.055-125.274 \mu \mathrm{g} / \mathrm{l}$ ) and the lowest in other seasons (ranges: $7.071-77.321 \mu \mathrm{g} / \mathrm{l}$ ), contrary to $\mathrm{PO}_{4}-\mathrm{P}_{2}$ (ranges: $15.099-116.107 \mu \mathrm{g} / \mathrm{l}$ ). These levels of the different kinds of nutrients in different khors provided a suitable situation for the growth of some macrobenthic invertebrates. For instance, molluscs and oligochaetes were found to mainly depend on $\mathrm{NO}_{2}$ and $\mathrm{PO}_{4}$, respectively while the former group was negatively correlated with $\mathrm{NO}_{3}$ (Table $5 \& 6$ ). These observations are in accordance with the results of Yuan (2010) and Iskaros and El-Otify (2013). In this context, Ali et al. (2007) concluded that the diversity and composition of aquatic invertebrates communities could be determined by nutrients. The high level of $\mathrm{NO}_{2}-\mathrm{N}$ during winter and spring may be attributed to the oxidation of the existing ammonia yielding nitrite as intermediate state or due to the decomposition of algae, bacteria and aquatic macrophytes. Contrarily, a relative decrease was detected in the nitrite a contents during summer, probably due to their reduction into ammonia, as well as being uptaken by the phytoplankton (Toufeek \& Korium, 2014). Such decrease in $\mathrm{NO}_{3}-\mathrm{N}$ may also be attributed to the effect of the incoming flood or to its utilization by phytoplankton (Zaghloul, 1985). 
The importance of phytoplankton in the natural habitats lies in the fact that it forms the main food supply for the aquatic organisms, including herbivorous zooplankton and macrobenthic invertebrates which ingest detritus (Iskaros, 1993). The previous author added that the difference in groups of benthos serve as important diet for various fish species in Khor Kalabsha. Thus, the chironomid larvae, particularly Dicrotiendipes modestus, Procladius sp. and Nilodorum were found to form the major food items for Mormyrus Kannume, M. caschive and Chrysichthys auratus throughout the different seasons. Synodontis shall and S. serratus feed mainly on gastropods, Bulinus truncatus and Physa acuta. Nymphs of Odonata and Ephemeroptera, larvae of Trichoptera, Corixidae are also infrequently recorded in the guts of the above 5 fish species. Hydrocynus spp., particularly H. forskulii, subsist mainly on insect larvae in winter.

Lake Nasser is considered one of the highly eutrophic lakes (Samaan, 1971; Fead, 1980; Habib, 1998). Furthermore, the trophic state index of the lake (TSI: $56.4-66.1$ on average 61) estimated in the study of Hussian et al. (2015) indicated eutrophic conditions according to Carlson (1971).

Results of the macrobenthic invertebrates in the northern khors of Lake Nasser during the present investigation gave an annual average biomass of $14.1 \mathrm{GFW} / \mathrm{m}^{2}$ at the littoral sites and $6.0 \mathrm{GFW} / \mathrm{m}^{2}$ at the offshores. Hence, it appears that such khors harbored higher values than most of the shallow Egyptian Delta Lakes (Table 7). In turn, these values are close to that recorded for Lake Nasser as a whole during the period of July 1986 - April, 1987 and most recorded for Aswan Reservoir. However, during the former period as well as the period that extended from October 1989 - September 1990, Khor Wadi-Abyad and Khor Kalabsha gave an annual average biomass of 36.0 and $33.9 \mathrm{GFW} / \mathrm{m}^{2}$, respectively. Similarly, the number of recorded species in the present investigation surmounted to 27 compared to 39 taxa recorded during the previous studies (Iskaros, 1988, 1993). Thus, the decline of both qualities and quantities of macrobenthic invertebrates in the present study may be attributed to the shortage of submerged macrophytes resulting from the illegal fishing tools used by some fishermen such as electric current, chemical substances and gas cylinders as well as the cultivation near the shores which may collectively cause a great damage to the aquatic plants that are very important for the development of the macrchenthic invertebrates at the littoral zone.

Shannon $(\mathrm{H})$ diversities analysis presented in Table (4) show considerable differences among the four investigated khors as well as their sectors. Thus, the highest total species (S:21-22), abundance (N: 1771- 3399) and species richness (S.R: 2.48 - 2.64) were estimated at Khors El-Ramla and Kalabsha, compared to Khor Rahma and Wadi-Abyad which may be related to the unfavorable conditions of their development created by rarely occurrence or disappearance of submerged macrophytes.

On the other hand, Regression analysis of macrobenthic invertebrate groups (Table 5) indicates the followings:

1) Aquatic Insecta was the dominant element, stepwise multiple regression analysis indicated that water temperature is the factor affecting abundance and distribution of aquatic insects and the model equation is:

Total density of aquatic insects specimens $/ \mathrm{m}^{2}=6059.140-194.982$ water temperature . 
2) Oligochaetae was the second dominant element, stepwise multiple regression analysis indicated that organic matter was the only factor that affects oligochaetes abundance and distribution in the eight investigated sites and the model equation is:

Total density of oligochaetes specimens $/ \mathrm{m}^{2}=1531.626-201.798$ organic matter.

3) Mollusca was the third dominant group, stepwise multiple regression analysis indicated that calcium carbonate was the only factor that affects mollusca abundance and distribution in the eight investigated sites and model equation is:

Total density of molluscs specimens $/ \mathrm{m}^{2}=91.734+29.264$ calcium carbonate.

4) Total macrobenthic invertebrates, stepwise multiple regression analysis indicated that water temperature is the only factor affecting abundance and distribution of total macrobenthic invertebrates and the model equation is:

Total density of macrobenthic invertebrates specimens $/ \mathrm{m}^{2}=7718.116-225.146$ water temperature.

Table 4. Total species (S), total individual (N), species richness (SR), evenness index (EI), Shannon diversity index $(\mathrm{H})$ during the period of investigation

\begin{tabular}{lllcccc}
\hline \multirow{2}{*}{ Station } & & \multicolumn{5}{c}{ Results } \\
\cline { 3 - 7 } El-Ramla & S & N & SR & E & H $^{\prime}$ \\
\cline { 3 - 7 } Kalabsha & Sec. I & 22 & 3399 & 2.57 & 0.76 & 2.35 \\
& Sec. II & 21 & 3124 & 2.48 & 0.74 & 2.26 \\
\multirow{3}{*}{ Rahma } & Sec. I & 21 & 1771 & 2.67 & 0.90 & 2.74 \\
& Sec. II & 22 & 2795 & 2.64 & 0.84 & 2.61 \\
\multirow{3}{*}{ Wadi Abyad } & Sec. I & 16 & 957 & 2.18 & 0.87 & 2.41 \\
& Sec. II & 14 & 693 & 1.98 & 0.91 & 2.42 \\
& Sec. I & 14 & 1731 & 1.74 & 0.79 & 2.09 \\
& Sec. II & 15 & 1419 & 1.91 & 0.55 & 1.49 \\
\hline
\end{tabular}


Table 5. Stepwise multiple regressions between macrobenthic invertebrate taxa with ecological factors at the studied sites during the period of investigation

\begin{tabular}{|c|c|c|c|c|c|c|c|c|c|}
\hline Dependent variable & Selected variable & $\mathrm{R}$ & $\mathrm{R}^{2}$ & $\begin{array}{l}\text { Std. Error of } \\
\text { the Estimate }\end{array}$ & \multicolumn{2}{|c|}{$\begin{array}{c}\text { Unstandardized } \\
\text { coefficient }\end{array}$} & $\begin{array}{l}\text { Standardized } \\
\text { coefficient }\end{array}$ & $\mathrm{t}$ & Sig. \\
\hline $\begin{array}{l}\text { Odonata (Anisoptera) } \\
\text { nymphs }\end{array}$ & Constant & 0.548 & 0.300 & 67.20639 & 170.965 & 37.341 & & 4.578 & 0.00 \\
\hline \multirow{2}{*}{ Diptera: chironomid larvae } & Constant & \multirow{2}{*}{0.511} & \multirow{2}{*}{0.261} & \multirow{2}{*}{670.10259} & -1889.592 & 751.433 & & -2.515 & 0.018 \\
\hline & Dissolved oxygen & & & & 314.516 & 96.525 & 0.511 & 3.258 & 0.003 \\
\hline \multirow{2}{*}{ Ephemeroptera nymphs } & Constant & \multirow{2}{*}{0.487} & \multirow{2}{*}{0.237} & \multirow{2}{*}{271.59472} & 592.302 & 150.902 & & 3.925 & 0.00 \\
\hline & Water temperature & & & & -138.113 & 38.145 & -0.621 & -3.621 & 0.001 \\
\hline \multirow[t]{3}{*}{ Hemiptera (adult) } & Organic matter & \multirow[t]{4}{*}{0.675} & \multirow[t]{4}{*}{0.456} & \multirow[t]{4}{*}{610.84599} & 172.871 & 58.146 & 0.467 & 3.079 & 0.005 \\
\hline & Chlorophyll-a & & & & -119.225 & 46.645 & -0.373 & -2.557 & 0.016 \\
\hline & Manganes & & & & -0.714 & 0.335 & -0.356 & -2.131 & 0.042 \\
\hline \multirow[t]{2}{*}{ Valvata nilotica } & Constant & & & & -181.449 & 77.761 & & -2.333 & 0.027 \\
\hline & $\mathrm{CaCO}_{3}$ & 0.580 & 0.336 & 180.09107 & 13.984 & 4.156 & 0.580 & 3.365 & 0.002 \\
\hline Bulinus truncatus & Trans. & 0.750 & & & -33.122 & 15.869 & -0.265 & -2.087 & 0.046 \\
\hline & Constant & & & & 339.021 & 68.785 & & 4.929 & 0.00 \\
\hline Melanoldes tuberculata & Nitrite & 0.537 & 0.289 & 123.19913 & -53.564 & 15.344 & -0.537 & -3.491 & 0.002 \\
\hline Physa acuta & Constant & 0382 & 0146 & 8197012 & 26.606 & 21.735 & & 1.224 & 0.230 \\
\hline Pnysa. асита & $\mathrm{CaCO}_{3}$ & 0.382 & 0.146 & 81.97012 & 4.077 & 1.802 & 0.382 & 2.262 & 0.031 \\
\hline Total benthos & Constant & 0.439 & 0.192 & 1628.65141 & 7718.116 & 2163.839 & & 3.567 & 0.001 \\
\hline 1otal benthos & Water temperature & 0.439 & 0.192 & 1028.05141 & -225.146 & 84.236 & -0.439 & -2.673 & 0.012 \\
\hline
\end{tabular}


Table 6. Correlation coefficients for association between physic-chemical parameters, heavy metals and macrobenthic invertebrate groups at eight sites during the period of investigation

\begin{tabular}{|c|c|c|c|c|c|c|c|c|c|c|c|c|c|c|c|c|}
\hline & A.Ins & Mol & Oli & $\mathrm{T}^{*}$ & $\mathrm{O}_{2} *$ & $\mathrm{pH}^{*}$ & Cond.* & Chlo-a & $\mathrm{NO}_{2}$ & $\mathrm{NO}_{3}$ & $\mathrm{PO}_{4}$ & $\mathrm{Fe}$ & $\mathrm{Mn}$ & $\mathrm{Zn}$ & $\mathrm{Cu}$ & O.M* \\
\hline$\overline{\mathrm{Mol}}$ & 0.206 & & & & & & & & & & & & & & & \\
\hline Oli & 0.591 & 0.116 & & & & & & & & & & & & & & \\
\hline $\mathrm{T}$ & -0.611 & 0.032 & -0.512 & & & & & & & & & & & & & \\
\hline $\mathrm{O}_{2}$ & 0.058 & 0.664 & 0.154 & -0.139 & & & & & & & & & & & & \\
\hline $\mathrm{pH}$ & -0.781 & 0.135 & -0.883 & 0.524 & -0.147 & & & & & & & & & & & \\
\hline Cond & 0.592 & -0.175 & 0.879 & -0.240 & 0.305 & -0.895 & & & & & & & & & & \\
\hline Chlo-a & -0.125 & -0.658 & 0.306 & -0.319 & -0.292 & -0.387 & 0.452 & & & & & & & & & \\
\hline $\mathrm{NO}_{2}$ & -0.194 & 0.522 & -0.368 & 0.341 & 0.431 & 0.549 & -0.507 & -0.804 & & & & & & & & \\
\hline $\mathrm{NO}_{3}$ & -0.193 & -0.763 & 0.116 & 0.052 & -0.274 & -0.153 & 0.287 & 0.633 & -0.231 & & & & & & & \\
\hline $\mathrm{PO}_{4}$ & 0.299 & -0.477 & 0.540 & 0.172 & 0.059 & -0.590 & 0.835 & 0.555 & -0.424 & 0.643 & & & & & & \\
\hline $\mathrm{Fe}$ & -0.203 & -0.208 & -0.236 & 0.113 & 0.001 & 0.409 & -0.163 & -0.175 & -0.034 & 0.617 & 0.189 & & & & & \\
\hline $\mathrm{Mn}$ & 0.201 & -0.129 & -0.033 & 0.071 & 0.247 & 0.163 & 0.121 & -0.281 & -0.195 & 0.215 & 0.288 & 0.752 & & & & \\
\hline $\mathrm{Zn}$ & 0.139 & -0.269 & 0.013 & 0.395 & -0.415 & -0.076 & 0.155 & 0.010 & -0.391 & 0.056 & 0.249 & -0.273 & -0.398 & & & \\
\hline $\mathrm{Cu}$ & -0.119 & -0.272 & -0.296 & 0.330 & -0.298 & 0.077 & -0.262 & 0.294 & 0.023 & 0.235 & -0.173 & 0.298 & 0.261 & -0.735 & & \\
\hline O.M & -0.121 & -0.023 & -0.490 & 0.356 & -0.404 & 0.349 & -0.364 & 0.204 & -0.004 & 0.124 & -0.084 & 0.301 & 0.309 & -0.261 & 0.569 & \\
\hline $\mathrm{CaCO}_{3}$ & -0.042 & 0.573 & -0.378 & 0.286 & 0.115 & 0.366 & -0.350 & -0.249 & 0.184 & -0.634 & -0.384 & -0.084 & 0.354 & -0.340 & 0.214 & 0.605 \\
\hline
\end{tabular}

* After Wahab et al. (2018) 
Table 7. Average biomass of macrobenthic invertebrates $\left(\mathrm{GFW} / \mathrm{m}^{2}\right)$ in Lake Nasser and in the different lakes in Egypt

\begin{tabular}{lcl}
\hline Lake & GFW/m & Author \\
\hline Lake Nasser (the northren khors) & 14.1 & Mohammed (2018) \\
Lake Nasser & 13.1 & Iskaros (1988) \\
Khor Wadi-Abyad & 36.0 & Iskaros (1993) \\
Lake Nasser (khor Kalabsha) & 33.9 & Iskaros (1988) \\
& 17.9 & Iskaros \& Gindy (2009) \\
Aswan Reservoir & 15.4 & Iskaros \& El-Otify (2013) \\
& 15.5 & Elster \& Jensen (1960) \\
Nozha Hydrodrome & 6.3 & Samaan (1977) \\
Lake Edku & 11.3 & Aboul- Ezz (1984) \\
Lake Burollus & 9.9 & \\
\hline
\end{tabular}


Table 8. Stepwise multiple regressions between benthic fauna groups with ecological factors at the studied sites during the period of investigation

\begin{tabular}{|c|c|c|c|c|c|c|c|c|c|}
\hline \multirow{2}{*}{$\begin{array}{l}\text { Dependent } \\
\text { variable }\end{array}$} & \multirow{2}{*}{ Selected variable } & \multirow{2}{*}{$\mathrm{R}$} & \multirow{2}{*}{$\mathrm{R}^{2}$} & \multirow{2}{*}{$\begin{array}{l}\text { Std. Error of } \\
\text { the Estimate }\end{array}$} & \multicolumn{2}{|c|}{ Unstandardized coefficients } & \multirow{2}{*}{$\begin{array}{l}\text { Standardized } \\
\text { coefficient }\end{array}$} & \multirow[t]{2}{*}{$\mathrm{t}$} & \multirow[t]{2}{*}{ Sig. } \\
\hline & & & & & B & Std. Error & & & \\
\hline \multirow[t]{2}{*}{ Aquatic Insecta } & Constant & \multirow{2}{*}{0.611} & \multirow{2}{*}{0.373} & \multirow{2}{*}{892.78431} & 6059.140 & 1186.161 & & 5.108 & 0.00 \\
\hline & Water temperature & & & & -194.982 & 46.176 & -0.611 & -4.223 & 0.00 \\
\hline \multirow[t]{2}{*}{ Oligochaetae } & Constant & \multirow{2}{*}{0.402} & \multirow{2}{*}{0.161} & \multirow{2}{*}{976.39688} & 1531.626 & 465.101 & & 3.293 & 0.003 \\
\hline & Organic matter & & & & -201.798 & 83.964 & -0.402 & -2.403 & 0.023 \\
\hline \multirow[t]{2}{*}{ Mollusca } & Constant & \multirow{2}{*}{0.677} & \multirow{2}{*}{0.458} & \multirow{2}{*}{264.13323} & 91.734 & 70.038 & & 1.310 & 0.200 \\
\hline & Calcium carbonate & & & & 29.264 & 5.808 & -0.677 & 5.038 & 0.00 \\
\hline \multirow[t]{2}{*}{ Hirudinea } & Constant & \multirow{2}{*}{0.378} & \multirow{2}{*}{0.143} & \multirow{2}{*}{32.60965} & 47.345 & 15.533 & & 3.048 & 0.005 \\
\hline & Organic matter & & & & -6.264 & 2.804 & -0.378 & -2.234 & 0.033 \\
\hline
\end{tabular}




\section{CONCLUSION}

The macrobenthic invertebrates in the northern khors of Lake Nasser were relatively rich in density. Numerically, aquatic insects were the main components followed by oligochaetes and molluscs. The littoral sites had the highest density of macrobenthic invertebrates (avg. 1986 ind. $/ \mathrm{m}^{2}$ with $14.1 \mathrm{GHW} / \mathrm{m}^{2}$ ), compared to the offshore ones (avg. 428 ind. $/ \mathrm{m}^{2} \& 6.0 \mathrm{GFW} / \mathrm{m}^{2}$ ). The seasonal variations of such biota at the littoral sites peaked during winter and autumn, coinciding with the falling of water temperature, while they remained less abundant in spring and summer, parallel with the increased values of both $\mathrm{pH}$ and water temperature. On the other hand, their occurrence at the offshore sites remained low throughout most of the year due to the shortage of suitable substrate.

\section{REFERENCES}

Aboul Ezz, S.M. (1984). Limnological investigations on zooplankton and benthos in Lake Burollus, Ph.D. Thesis, Faculty of Science, Mansoura University, 340pp.

Ali, M.M.; Mageed, A.A. and Heikal, M. (2007). Importance of aquatic macrophyte for invertebrates diversity in large subtropical reservoir. Limnologica-Ecology and Management of Inland Waters, 37(2), 155-169.

American Public Health Association. (APHA, 1992). Water Environment Federation. Standard methods for the examination of water and wastewater, $18^{\text {th }}$ edit. New York.

American Public Health Association. (APHA, 1995). Water Environment Federation. Standard methods for the examination of water and wastewater.New York.

Angradi, T.R., Schweiger, E.W. and Bolgrien, D.W. (2006). Inter-habitat variation in the benthos of the Upper Missouri River (North Dakota, USA): implications for Great River bioassessment. River Research and Applications, 22(7), 755-773.

Bishai, H.M.; Abdel-Malak, S.A. and Khalil, M.T. (2000). Encyclopedia of Lake Nasser. Publication of National Biodiversity Unit-No.11-2000, pp 577.

Brinkhurst, R.O. and Jamieson, B.G.M. (1971). Aquatic Oligochaetae of the world. Univ. Tornto press, Ont.860 pp.

Brown, D.S. (1980). Fresh water snails of Africa and their medical importance. Lond., Taylor \& Francis Ltd, 478pp.

Brown, D.S.; Fison, T.; Southgate, V.R. and Wright, C.A. (1984). Aquatic snails of the Jonglei region, southern Sudan, and transmission of trematode parasites. Hydrobiol., 110:247-271.

Bury, N. and Grosell, M. (2003). Iron acquisition by teleost fish.Comparative Biochemistry and Physiology Part C: Toxicology \& Pharmacology, 135(2), 97-105.

Byres, C.; Mills, E.L. and Stewart, P.L. (1978). A comparison of methods of determining organic carbon in marine sediments with suggestions for a standard method Hydrobiologia, 58:43-47.

Carlson, R.E. (1977). A trophic state index for lakes. Limnol. Oceanogr., 22(2): 361 - 369.

Carver, R.E. (1971). Procedures in Sedimentary Petrology. John Wiley, London, New York, Sydney, Toronto, 633 pp. 
Demian. E.S. (1959). On the fresh water gastropods of Dakhla and kharga Oases. Bull. Zool. Soc. Egypt, 14:17-21.

El-Dardir, M. (1984). Geochemical and sedimentological studies on the sediments of Aswan High Dam Reservoir. Ph.D. Thesis, Al-azhar Univ., Cairo, Egypt, 238pp.

El-Dardir, M. (1995). Mineralogical and geochemical studies on the recent Nile sediments of the area between the old Aswan Dam and High Dam. Bulletin of Fac. Sci, Menoufia Univ., 8:205-211.

El-Duweini, K.A. and Ghabbour, S.I. (1963). Study of the specific distribution of megadriline oligochaetes in Egypt and its dependence on soil properties. Bull. Zool. Soc. Egypt, 18:21-30.

Entz, B.A.G. (1973). Morphometry of Lake Nasser and Lake Nubia. Lake Nasser Development Center, working paper, No.2 Aswan; 90pp.

Entz, B.A.G. (1974). Limnology. In. B.A.G. Entz and A. F. A. Latif (Eds.), Report on survey to Lake Nasser and Lake Nubia (1972-1973). Lake Nasser Development Centre, working paper. No 6, Aswan; 4-63.

Entz, B.A.G. (1978). Sedimentation processes in the Reservoir Lake Nasser-Nubia during 1965-1974 and future aspects. Symposium of Ecological Studies on the River Nile. Egyptian Society of Environment, Cairo,( April, 1978).

Farahat, H.I.H. (2010). Particle size distribution and geochemical studies on the recent sediment of Damietta and Rosetta Branches. Ph.D. Thesis. Fac. Sci, Banha Univ., Egypt. 227pp.

Fead, E.M. (1980). Primary production of Lake Nasser. Thesis to School of public Health, Michigan Univ.

Fishar, M.R. and Williams, W.P. (2006). A feasibility study to monitor the macroinvertebrates diversity of the River Nile using three sampling methods. Hydrobiologia, 556, 137 - 147.

Fishar, M.R.A. (1995). Studies on bottom fauna in Lake Nasser, Egypt. Ph.D. Thesis. Fac. Sci, Suez Canal Univ., Egypt. 267pp.

Habib, O.A. (1998). The phytoplankton of Lake Nasser, Egypt. High Dam Lake development Authority, June 20-23,1998. Aswan, Egypt.

Hann, B.J. (1995). Invertebrates as sociations with submersed aquatic plants in a prairie wetland. USF (Delta Marsh) Annual report, Vol. 30.

Hanna, A. (1965). Organic matter in soil, In chemistry of soil $2^{\text {nd }}$. ed. Bear F. E, American Chem. Soc. Monograph series, New York.

Heikal, M.T. and Abdel Bary, M.R. (1999). Stratification variability and trophic state along Lake Nasser. In Lake 99, Eighih international conference on the conservation and management of lakes, Copenhagen.

Hepp, Lu., Landeiro, VL. and Melo, AS. (2012). Experimental assessment of the effects of environmental factors and longitudinal position on alpha and beta diversities of aquatic insects in a neotropical stream. International Review of Hydrobiology 97: $157-167$.

Hilsenhoff, W.L. (1975). Aquatic Insecta of Wisconsin with generic keys and notes on biology, ecology and distribution. Tech. Bull. no. 89. Dept. Nat. Res., Mdison, Wisconsin, 55pp. 
Hussian A.M.; Napiórkowska-Krzebietke A.; Toufeek M.E.F. and Abd El-Monem A.M., Morsi H.H. (2015). Phytoplankton response to changes of physicochemical variables in Lake Nasser, Egypt. J. Elem., 20(4): 855-871.

Ibrahim, A.M.; Bishai, H.M. and Khalil, M.T. (1999). Fresh water molluscs of Egypt. Publication of National Biodiversity Unit, No.10.

Iskaros, I.A. (1993): Ecological studies on the distribution of zooplankton and bottom fauna in Khor Kalabsha in lake Nasser. Ph.D. Thesis, Fac. Sci, Mansoura Univ., 304 pp.

Iskaros, I.A. and El-Dardir, M. (2010). Factors affecting the distribution and abundance of bottom fauna in Lake Nasser, Egypt. Nature and Science. 8:95-108.

Iskaros, I.A. and El-Otify, A.M. (2013). Seasonal periodicity of plankton and benthic fauna community structure and diversity in a small North African reservoir. Water and Environmental Journal. 27:561-574.

Iskaros, I.A.; Gindy, N.N. and El-Dardir, M. (2011). Long-term fluctuations of macrobenthic invertebrates in Aswan Reservoir, Egypt. International Journal of Environmental Science and Engineering (IJESE). 1:37-48.

Iskaros, J.A. (1988). Biological studies on bottom fauna in Lake Nasser and adjacent waters. M.Sc. Thesis, Fac. Sci, Alexandria Univ., 184 pp.

Jiang, X.M., Xiong, J. Qiu, J.W., Wu, JM. Wang, JW. and Xie, ZC. (2010). Structure of macroinvertebrate communities in relation to environmental variables in a subtropical Asian river system. International Review of Hydrobiology 95, 42-57.

Kouadia, L. and Trefry, J.H. (1987). Sediment trace metal contamination in the Ivory coast west Africa, water, air and soil pollution 32:145-154.

Latif, A.F.A. (1974). Fisheries of Lake Nasser. Aswan Regional Planning, Lake Nasser Development Centre. Aswan, 235 pp.

Latif, A.F.A.; El-Etreby, S.G. and Iskaros, I.A. (1979). Bottom fauna of High Dam Reservoir. Report, River Nile and Lake Nasser Project. Acad. Sci. Technol., Cairo.

Mageed, A.A. and Heikal, M.T. (2006). Factors affecting seasonal patterns in epilimnion zooplankton community in one of the largest man-made lakes in Africa (Lake Nasser, Egypt). Limnologica 36:91-97.

Marker, A.F.H.; Nusch, E.A.; Rai, H. and Rieman, B. (1980). The measurements of photosynthetic pigments in fresh water and standardization of methods conclusions and recommendations. Archive für Hydrobiologie-Beihefi. Ergebnisse der limnologie, $14,91-106$.

Mason, W.T. (1973). An introduction of chironomid larvae. Analytical quality control Laboratory. Nat. Environ. Res. Center. U.S. Environmental protection Agency. Cincinanti, Ohio, 90pp.

Merritt, R.W.; Cummins, K.W. and Berg, M.B. (2008). An introduction to the Aquatic Insecta of North America, fourth ed. Kendall Hunt Publishing, Dubuque, Iowa, USA.

Mola, H.R.A. and Abdel Gawad, S.S.A. (2014). Spatio-temporal variations of macrobenthic fauna in Lake Nasser khors, Egypt J. Aquat. Res., 40(4):415-423.

Moore, J.W. (2006). Animal ecosystem engineers in streams. Bioscience 56, 237 - 246.

Payne, A.I. (1986). The ecology of tropical lakes and rivers. John wiley and sons. Chichester, New York. Toronto, Brisbane and Singaphore, 300pp. 
Pennak, R.W. (1978). Fresh water invertebrates of the United State. $2^{\text {nd }}$ edition. John Wiley and sons. New York, 803pp.

Samaan, A.A. (1971). Report on the trip of Lake Nasser to investigate its primary productivity during March 1971. Report for Lake Nasser Development Centre. Aswan, $11 \mathrm{pp}$.

Silva DRO; Ligeiro R.; Hughes RM. and Callisto M. (2014). Visually determined stream mesohabitats influence benthic macroinvertebrates assessments in headwater streams. Environmental Monitoring Assessment. 186: 5479 - 5488.

Smith, R.E. and Pritchard, A.E. (1968). Odonata, P., 106 - 153. In: R.L. Usinger, Aquatic Insecta of California Univ. Calif. Pr. Los Angeles.

Talling, J.F. and Talling, T.B. (1965). The chemical composition of African lake waters. International Revueder Gesamten. Hydrobiologie, 50(3):421-463.

Toufeek, M.A.F. and Korium, M.A. (2014). Physico-chemical characteristics of Lake Nasser water. In: Goher, Environmental and biological monitoring of Lake Nasser for forecasting the impacts of the Ethiopian Renaissance Dam. (5): 63 - 97.

Vanni, M.J. (2002). Nutrient cycling by animals in freshwater ecosystems. Ann. Rev. Ecol. Syst. 33: $341-370$.

Welch, P.S. (1952). Lomnology. $2^{\text {nd }}$ edition New York, Toronto, London, MC. Grew, Hill book company, Inc., 538pp.

Wirth, W.W. and Stone, A. (1968). Aquatic Diptera, $2^{\text {nd }}$ edition. p. 372-482. In: R.L. Usinger (Ed.), Aquatic Insecta of California. Univ. Calif. pr. Los Angeles.

Wurts, W.A. (2003). Daily pH cycle and ammonia toxicity. World Aquaculture 34(2): 20 21.

Yuan, J. (2010). Improving the antitumor effect of genistein with abiocompatible super paramagnetic during delivery system J. Nanosci. Nanotechnol.10(4), pp. 2325-2331.

Zaghloul, F.A. (1985). Seasonal variations of plankton in Lake Nasser. Ph.D. Thesis, Fac. Sci., Suze Canal Univ., 364pp. 